\title{
Composition and distribution of diatom assemblages from core and surface sediments of a water supply reservoir in Southeastern Brazil
}

\author{
Samantha Borges Faustino ${ }^{1,3}$, Luciane Fontana ${ }^{2}$, Elaine Cristina Rodrigues Bartozek ${ }^{1}$, \\ Carlos Eduardo de Mattos Bicudo ${ }^{1}$ \& Denise de Campos Bicudo ${ }^{1}$ \\ ${ }^{1}$ Instituto de Botânica, Department of Ecology, Avenida Miguel Estéfano, 3687, 04301012, \\ São Paulo, SP, Brazil. \\ ${ }^{2}$ Universidade Federal Fluminense, Departamento de Geoquímica, Niterói, Rio de Janeiro, Brazil. \\ ${ }^{3}$ Corresponding author: Samantha Borges Faustino, e-mail: sbfaustino@gmail.com
}

FAUSTINO, S.B., FONTANA, L., BARTOZEK, E.C.R., BICUDO, C.E.M., BICUDO, D.C. Composition and distribution of diatom assemblages from core and surface sediments of a water supply reservoir in Southeastern Brazil. Biota Neotropica. 16(2): e20150129. http://dx.doi.org/10.1590/16760611-BN-2015-0129

\begin{abstract}
Fresh water biodiversity is an increasing concern due to growing human impact. Herein, we report a long-term survey (ca. 90 years) of sedimentary diatoms and the modern flora from surface sediments and their biodiversity changes along a eutrophication gradient. Study was carried out in one of the most important water supply reservoirs (Guarapiranga Reservoir) of São Paulo Metropolitan Region, Brazil. Results are based on 75 core subsamples (subfossil assemblages from core) previously dated by ${ }^{210} \mathrm{~Pb}$ and 14 samples from surface sediments (modern assemblages). Overall, 84 taxa were reported, belonging to 30 genera, 71 species and eight non-typical varieties, besides five probable new taxa. Results expanded two new additions for the Brazilian diatom flora (Chamaepinnularia submuscicula and Stauroneis acidoclinata) and 30 infrageneric taxa for the state of São Paulo. $47.6 \%$ of total taxa inventoried were accounted exclusively for the subfossil assemblages indicating a significant biodiversity change over time. Access to past oligotrophic conditions and to contemporary mesotrophic regions of the Guarapiranga Reservoir accounted for these new additions representing $25 \%$ of the total diatom flora. Decline in the total species number along the trophic state gradient occurred for subfossil and modern assemblages. This pattern was even clearer when considering the changes in species richness over time. Eunotia with 21 taxa was the far most represented genera particularly in the oligotrophic phase. During the transitional period (1947-1974), richness gradually declined. With the onset (in the 1970s) and the major eutrophication period (since ca. 1990) occurred a drastic reduction in richness and the replacement of oligotrophic to eutrophic species. Human management also caused abrupt changes in richness. Marked decline occurred (1933) assotiated with hydrological impacts (water discharge increase) with the initial use of the reservoir as a public water supply. Unlike, sudden increase occurred probably associated with the application of algaecide to control cyanobacterial blooms. Present findings highlight the need for surveying the diatom assemblages in protected environments or in less degraded conditions for biodiversity assessment. Furthermore, reinforce the use of paleolimnological approach as in many cases the only tool to assess biodiversity changes encompassing time scales relevant to human-induced degradation and pre-anthropogenic impacts.
\end{abstract}

Keywords: Bacillariophyta, biodiversity change, eutrophication, Guarapiranga Reservoir, paleolimnology, species richness.

FAUSTINO, S.B., FONTANA, L., BARTOZEK, E.C.R., BICUDO, C.E.M., BICUDO, D.C. Composição e distribuição das diatomáceas de perfil sedimentar e sedimentos superficiais em reservatório de abastecimento no Sudeste do Brasil. Biota Neotropica. 16(2): e20150129. http://dx.doi.org/10.1590/ 1676-0611-BN-2015-0129

Resumo: A biodiversidade de águas continentais vem se tornando uma preocupação crescente devido ao grande aumento do impacto antropogênico nesses ambientes. Nosso objetivo foi documentar o inventário e a mudança da biodiversidade das comunidades de diatomáceas subfósseis ao longo de 90 anos e das diatomáceas recentes de sedimentos superficiais ao longo de um gradiente de eutrofização. O estudo foi realizado em um dos mais importantes reservatórios de abastecimento público (represa Guarapiranga) da Região Metropolitana de São Paulo, Brasil. Baseou-se na análise de 75 subamostras de um perfil sedimentar (comunidades subfósseis) previamente datado pelo ${ }^{210} \mathrm{~Pb}$ e em 14 amostras de sedimento superificial 
(comunidades recentes). Ao todo, identificamos 84 táxons, distribuídos em 30 gêneros, 71 espécies e oito variedades não típicas, além de cinco prováveis novidades taxonômicas. Os resultados acresceram duas novas citações para a flórula diatomológica do Brasil (Chamaepinnularia submuscicula e Stauroneis acidoclinata) e 30 táxons infragenéricos para o Estado de São Paulo. Desse total, 47,6\% foram identificados exclusivamente para as comunidades subfósseis indicando uma mudança significativa da biodiversidade ao longo do tempo. $\mathrm{O}$ acesso às condições oligotróficas pretéritas e às regiões mesotróficas recentes da represa foi responsável pelas novas adições que representaram $25 \%$ do total da diatomoflórula. Declínio do número total de espécies ao longo do gradiente de estado trófico foi observado para as comunidades de diatomáceas subfósseis e modernas. Esta tendência foi ainda mais evidente com base na alteração da riqueza de espécies ao longo do tempo. Eunotia com 21 táxons foi o gênero mais representado particularmente na fase oligotrófica da represa. Durante o período de transição (1947-1974) houve diminuição gradativa da riqueza. Com o início da eutrofização (década de 1970) e do período de maior eutrofização (desde 1990) ocorreu drástica redução da riqueza e substituição de espécies oligotróficas por eutróficas. Mudanças abruptas de riqueza de diatomáceas também foram observadas devido ao manejo da represa. Declínio marcado ocorreu (1933) associado a impactos hidrológicos (aumento da vazão) com o início do uso do reservatório para abastecimento público. De forma diferente, aumento repentino de riqueza ocorreu associado à aplicação de algicida para controlar as florações de cianobactérias. Os presentes resultados salientam a necessidade de levantamentos das comunidades de diatomáceas de ambientes protegidos ou em condições menos degradadas em estudos que visem o acesso à biodiversidade. Ademais, reforçam o uso da paleolimnologia como a única ferramenta, em muitos casos, que possibilita avaliar as mudanças da biodiversidade em escalas relevantes para acessar a degradação induzida pelo homem e períodos pré-impactados.

Palavras-chave: Bacillariophyta, mudança de biodiversidade, eutrofização, represa Guarapiranga, paleolimnologia, riqueza de espécies.

\section{Introduction}

Despite covering just $0.8 \%$ of the Earth's surface, freshwater ecosystems are considered hotspots for biodiversity supporting $\sim 6 \%$ of all described species (Dudgeon et al. 2006). However, the growing anthropogenic impacts in the last century has led to growing threats to fresh water biodiversity as well as to the largely "unknown" diversity worldwide (Strayer \& Dudgeon 2010). Decreases in biodiversity are so widespread that they are now considered a form of global change (Gregory-Eaves \& Beisner 2011). Therefore, information on biodiversity changes in long timescales has become an important issue of freshwater ecology and conservation.

Given long-term community data are sparse and usually span no more than five years, the paleolimnological approach has recently been highlithed as an emerging field for biodiversity science (Gregory-Eaves \& Beisner 2011). Lake sediments integrate organisms over time and space, different habitats, providing whole-lake, annual to multi-annual assemblage information more efficiently than neolimnological studies (Bennion 1995, Gregory-Eaves \& Beisner 2011). They can provide valuable information about past and contemporary environmental conditions, having good records of biodiversity (Froyd \& Willis 2008, Liu et al. 2012, Davidson et al. 2013) and floristic changes (Schmidt et al. 1990).

Among the biological groups preserved in the sediments, diatoms have been widely used because of their taxonomic distinction, abundance, good preservation in sediments and their rapid response to environmental changes (Reid 2005, Bennion \& Simpson 2011). The use of diatoms as indicators of environmental changes require high taxonomic precision (Birks 1994), since misidentifications can modify the interpretation in obtaining reliable data on modern diatom biodiversity (Buczkó \& Magyari 2007, Wetzel \& Ector 2014). Also relevant is the auto-ecological knowledge of diatom species in order to use them as modern analogues in quantitative paleo-environmental reconstruction using sediment records of past communities (Birks 1994). Moreover, past communities are very often the only available tool to provide information on natural biodiversity before human impacts, such as cultural eutrophication. For those purposes, floristic surveys in long time series are considered crucial (Schmidt et al. 1990), though rarely available in the world, especially in tropical regions

There has been an increasing knowledge of the diatom flora in some regions of Brazil (e.g. Ferrari \& Ludwig 2007, Melo et al. 2010, Wetzel et al. 2010, Santos et al. 2011, Bartozek et al. 2013). However, only recently taxonomical studies of surface sediments have began (Fontana \& Bicudo 2009, 2012, Silva \& Bicudo 2014), including the addition of new species (Wengrat et al. 2015, Almeida et al. 2015).

Despite the studies on paleoenvironmental reconstruction using diatoms (e.g. Costa-Böddeker et al. 2012, Fontana et al. 2014), to our knowledge floristic and taxonomical studies of sedimentary diatoms in long timescale in Brazil and probably in tropical regions have not been published. We presently documented the floristic survey and the spatial-temporal distribution of diatoms from the surface sediments (modern flora) and core (ca. 90 years, subfossil flora) of the Guarapiranga Reservoir along a spatial and temporal eutrophication gradient. The subfossil diatom assemblage was taxonomically studied and revised based on the ecological study of Fontana et al. (2014). The Guarapiranga Reservoir is one of the most important public water supplies for the metropolitan region of São Paulo. Present study expands the knowledge of biodiversity changes, taxonomical and ecological information of tropical diatoms, contributing to their use in water quality bioassessment and paleoenvironmental reconstruction.

\section{Material and Methods}

Guarapiranga Reservoir is a strategic public water supply located in one of the most urbanized cities worldwide, the São Paulo Metropolitan Region (SPMR), in the state of São Paulo,

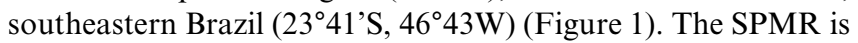
one of the most important financial, commercial and industrial 

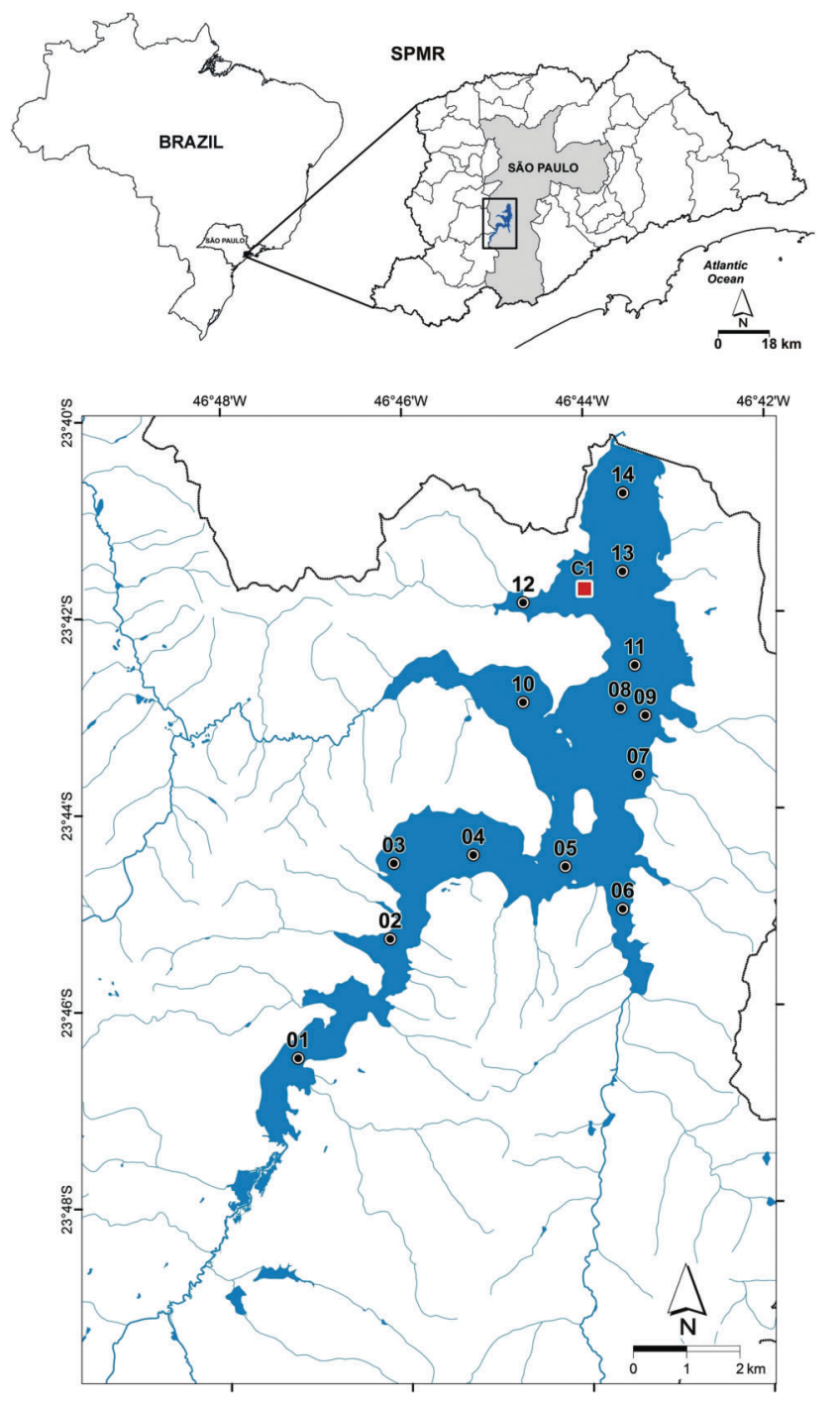

Figure 1. Map showing the location of the state of São Paulo in Brazil and the city of São Paulo metropolitan region (SPMR) with location of Guarapiranga Reservoir. Enlarged map of the reservoir with sampling sites: solid circles for surface sediments (1 to 14) and solid red square for core $\left(\mathrm{C}_{1}\right)$.

centers in Brazil, and one of the most densely populated areas of the country, with nearly 20 million inhabitants (IBGE 2014). The reservoir has an area of $36.18 \mathrm{~km}^{2}$, mean and maximum depth of 7 and $13 \mathrm{~m}$, respectively, and a water volume of $253 \times$ $106 \mathrm{~m}^{3}$ (Mozeto et al. 2001). It was built in 1906-1909 for energy production, and dam construction flooded a large portion of Atlantic Forest habitat (Whately \& Cunha 2006). In 1927, the city of São Paulo began to use the reservoir as a public water supply, and today the reservoir is the main water source for the city, supplying drinking water to about $25 \%$ of the population. Fontana et al. (2014) inferred the major ecological shifts (using diatoms and geochemical proxies) in the water body over the last 90 years related to multiple stressors, mainly the influence of forest flooding and eutrophication. The reservoir was oligotrophic from 1919 to 1947 and the onset of eutrophication occurred in the mid-1970s. By the early 1980s the reservoir had become eutrophic, in response to an explosive increase in human population in its watershed. Severe cultural eutrophication has persisted since 1990. Further information on the major shifts of the reservoir is available in Fontana et al. (2014).

Core was retrieved by divers from the northern area of the basin, close to the dam (Figure 1). The core chronology was determined by ${ }^{210} \mathrm{~Pb}$ dating as detailed in Fontana et al. (2014). Divers collected a 75-cm core in February 2010 using acrylic tube that was sectioned at $1 \mathrm{~cm}$ intervals. In total, 75 subsamples (slices) were examined (subfossil diatom flora). In addition, 14 samples of surface sediments (modern diatom flora) were collected in August/2011, using a gravity corer (UWITEC), and the first $2 \mathrm{~cm}$ of the sediments were saved for diatom analysis. Sampling stations for surface sediments covered the trophic spatial gradient of the reservoir (Figure 1). Limnological characteristics of these sites are provided in Table 1 (according to AcquaSed database Project). Subsurface samples in the limnetic zone were taken with a van Dorn sampler in the dry (August/2011) and rainy seasons (March/2011). Water temperature $\left({ }^{\circ} \mathrm{C}\right), \mathrm{pH}$ and conductivity $\left(\mu \mathrm{S} \mathrm{cm}{ }^{-1}\right)$ were measured in the field using standard electrodes (Horiba U-53). The analytical procedure for dissolved oxygen (DO, $\mathrm{mg} \mathrm{L}^{-1}$ ), ammonium $\left(\mathrm{N}-\mathrm{NH}_{4}\right.$ $\mu \mathrm{g} \mathrm{L}^{-1}$ ), nitrate $\left(\mathrm{N}-\mathrm{NO}_{3} \mu \mathrm{g} \mathrm{L}^{-1}\right)$, soluble reactive silica ( $\mathrm{SRS}, \mathrm{mg} \mathrm{L}^{-1}$ ),

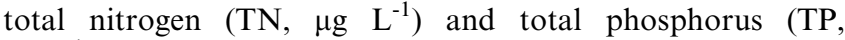
$\mu \mathrm{g} \mathrm{L}^{-1}$ ) followed Standard Methods (APHA 2005). Chlorophyll $a\left(\mu \mathrm{g} \mathrm{L}^{-1}\right)$, corrected for phaeophytin, was measured using $90 \%$ ethanol (Sartory \& Grobbelaar 1984). The Trophic State Index (TSI) was calculated according to Lamparelli (2004). For details, see Wengrat \& Bicudo (2011). Sampling sites 1 to 5 were considered mesotrophic, and 6 to 11 and 13 to 14 eutrophic, while site 12 was classified as supereutrophic (Table 1).

Diatom samples were oxidized according to standard procedures (Battarbee et al. 2001), using concentrated hydrogen peroxide $\left(\mathrm{H}_{2} \mathrm{O}_{2}, 35 \%\right)$ and hydrochloric acid $(\mathrm{HCl} \mathrm{37 \% )}$. Oxidized subsamples were rinsed with deionized water and permanent slides were prepared using Naphrax as mounting medium. Optical observations, measurements and micrographs were taken at a magnification of $1000 \times$ with a Zeiss Axioskop 2 plus microscope equipped with DIC and phase contrast, with an Axiocam ERc5s high-resolution digital camera. Micrographs were digitally manipulated and plates containing LM images were created using CorelDraw X6. Morphometric information is provided for all taxa (L: length; W: width; D: diameter; M: mantle height; S: striae; AS: apical striae; MS: median striae; F: fibulae, A: areolae; AC: alar canals; MF: mantle fultoportulae) as well as temporal and spatial distribution in the reservoir. Descriptions are presented for the new records for Brazil, and comments are provided when relevant (e.g. poorly known species worldwide or in Brazil). Taxonomy and nomenclature followed classic works and new publications (e.g., Hustedt 1950, Krammer 2000, Metzeltin et al. 2005, Lange-Bertalot et al. 2011) and the on-line catalogue of valid names (site of California Academy of Sciences 2012). The classification systems followed Medlin \& Kaczmarska (2004) for supra-ordinal taxa and Round et al. (1990) for subordinal taxa, except for genera published subsequently to this work. To account for the species distribution in Brazil and the state of São Paulo, literature with illustration or sufficient taxonomic description of the species was considered. Sediment samples were deposited at the "Herbário Científico do Estado Maria Eneyda P. Kauffmann Fidalgo" (SP), Brazil. Finally, to determine species richness (Magurran 2004) diatom was quantified to standardize the analytical procedure among samples. Enumeration was made at a magnification of 


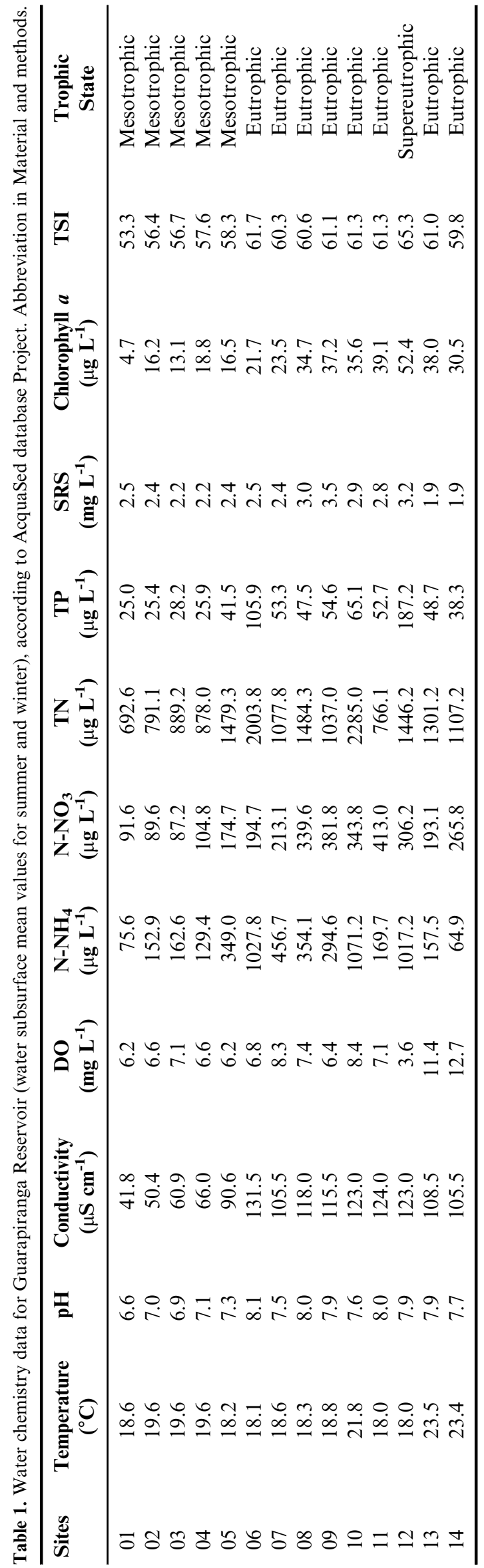

$1000 \times$ using a Zeiss Axioskop 2 microscope, and at least 400 valves were counted per slide (Battarbee et al. 2001).

\section{Results and discussion}

\section{Taxonomy and ecological preferences}

Below are presented the taxonomical aspects of the species identified in this study and their ecological preferences. Taxa preceded by one asterisk represent new records for the state of São Paulo, and those preceded by two asterisks are first citations for Brazil. The infrageneric taxa commonly reported in Brazilian literature are shown in Table 2.

\section{Aulacoseiraceae Crawford}

\section{Aulacoseira Thwaites}

*Aulacoseira granulata Ehrenberg var. australiensis Moro, Arquivos de Biologia e Tecnologia 34(2), p. 353-359, 1991.

Figs. 5-7.

M: $11.0-20.0 \mu \mathrm{m}$; D: $16.0-23.0 \mu \mathrm{m}$; S: $8-9$ in $10 \mu \mathrm{m}$; A: $8-11$ in $10 \mu \mathrm{m}$.

It differs from Aulacoseira granulata (Ehrenberg) Simonsen var. granulata mainly due to its greater diameter $(18.0-31.0 \mu \mathrm{m})$ and the presence of visible rimoportulae in LM in valve surface (Moro 1991). No ecological information was found in literature. This variety occurred in $2 \%$ of all samples in eutrophic conditions for subfossil and modern assemblages. This is the first report for the state of São Paulo.

Aulacoseira pusilla (Meister) Tuji \& Houk, Bulletin of the National Sciense Museum, Series B (Botany), Tokyo, 30 (2), p. 38, 2004. Figs. 10-11.

M: 2.0-2.6 $\mu \mathrm{m}$; D: 5.2-6.6 $\mu \mathrm{m}$; inconspicuous striae.

In Brazil, this species was commonly confused with $A$. alpigena (e.g. Brassac et al. 1999, Ludwig et al. 2005), A. distans (Ehrenberg) Simonsen (e.g. Ludwig et al. 2004, Raupp et al. 2006) or $A$. muzzanensis (e.g. Morandi et al. 2006). It is considered a cosmopolitan and eutrophic species (Houk \& Klee 2007, Taylor et al. 2007, Tuji \& Williams 2007). Presently distributed in $68 \%$ of the core samples (from oligo- to eutrophic phases). Our data expanded its ecological range from oligotrophic to mesotrophic conditions.

Aulacoseira tenella (Nygaard) Simonsen, Bacillaria 2, p. 63, 1979. Figs. 12-13 girdle view, Figs. 14-15 valve view.

M: $2.0-3.0 \mu \mathrm{m}$; D: $5.0-8.0 \mu \mathrm{m}$; $\mathrm{S}: 8-9$ in $10 \mu \mathrm{m}$.

This species was reported from oligotrophic to oligo-mesotrophic and slightly acidic to neutral waters (Siver \& Kling 1997, Wetzel 2011). Distributed in $60 \%$ of all samples from oligotrophic to mesotrophic (subfossil samples) and from mesotrophic to eutrophic conditions (modern samples).

Orthoseiraceae Kützing

Orthoseira Thwaites

Orthoseira roseana (Rabenhorst) O'Meara, Proceedings of the Royal Irirsh Academy, 2 p. 255, pl. 26, 1875.

Figs. 16-18.

D: $13.1-17.3 \mu \mathrm{m}$; M: observed only in valve view; $\mathrm{S}$ : $16-18$ in $10 \mu \mathrm{m}$; A: $18-22$ in $10 \mu \mathrm{m}$.

Distributed in $41 \%$ of the subfossil samples in past oligotrophic conditions.

Stephanodiscaceae Glezer \& Makarova

Cyclotella (Kützing) Brébisson 
Table 2. Valve dimensions and trophic state range distribution based on literature and in this study for the species recorded in Guarapiranga Reservoir that are commonly reported in Brazil.

\begin{tabular}{lccc}
\hline Taxon & Dimension $(\mu \mathrm{m})$ and striae & Ecology & Distribution in samples (S: subfossil; M: \\
modern diatoms)
\end{tabular}

\section{AULACOSEIRACEAE}

Aulacoseira ambigua (Grunow)

Simonsen (Figs. 2-3)

Aulacoseira granulata (Ehrenberg)

Simonsen var. angustissima (Müller)

Simonsen (Fig. 4)

Aulacoseira granulata (Ehrenberg)

Simonsen var. granulata (Figs. 8-9)

\section{STEPHANODISCACEAE}

Cyclotella meneghiniana

Kützing (Figs. 22-23)

Discostella pseudostelligera

(Hustedt) Houk \& Klee (Figs. 24-25)

Discostella stelligera (Cleve and

Grunow) Houk \& Klee (Figs. 26-27)

Spicaticribra rudis (Tremarin et al.)

Tuji et al. (Figs. 28-29)

\section{FRAGILARIACEAE}

Asterionella formosa Hassal

(Figs. 30-31)

EUNOTIACEAE

Eunotia camelus Ehrenberg

(Figs. 50-51)

Eunotia rabenhorstii var. monodon

Cleve \& Grunow in Van Heurck

(Figs. 62-63)

Eunotia zygodon Ehrenberg

(Fig. 70)

CYMBELLACEAE

Cymbopleura naviculiformis (Auerswald)

Krammer (Figs. 84-85)

Encyonema silesiacum (Bleisch) Mann

(Figs. 86-87)

\section{GOMPHONEMATACEAE}

Gomphonema laticollum Reichardt

(Figs 99-100)

\section{ACHNANTHIDIACEAE}

Achnanthidium minutissimum (Kützing)

Czarnecki (Figs. 107-109)

STAURONEIDACEAE

Capartogramma crucicula

(Grunow ex Cleve) Ross (Fig. 149)

\section{CATENULACEAE}

Amphora copulata (Kützing) L: 28.0-36.3; W:

Schoeman \& Archibald (Figs. 161-162)
M: 4.0-10.0; D: 5.0-6.6; S: 10-13; A: $10-16$

M: 10.0-20.0; D: 2.0-3.3;

S: $10-11 ; \mathrm{A}: 10-12$

M: 9.9-19.3; D: 5.2-12.6; Eutrophic $^{1}$

S: 8-10; A: 9-10

D: $13.8-22.0 ; \mathrm{S}: 7-9$

D: 5.0-8.0; S: 13-19; MF: Eutrophic $^{1}$

$7-12$

D: $9.7-17.5 ; \mathrm{S}: 13-16$

D: 15.3-22.6; S: 18-20; A: 16-18

\section{L: 42.5-60.0; W: 2.2-2.6; Eutrophic $^{1}$}

inconspicuous striae

L: 24.6-61.5; W: 4.6-7.0;

S: 9-11

L: 11.2-23.6; W: 5.0-8.1;

S: $12-13$

L: 66.0-76.2; W: 20.0; S: -

12

\section{L: 34.4-41.3; W: \\ 9.3-10.0; S: 11-14 \\ L: 35.0-40.0; W: 6.0-7.5; \\ S: $7-10$ \\ Tolerant ${ }^{2}$ \\ Tolerant $^{2}$ to indifferent ${ }^{1}$}

L: 34.6-51.2; W:

12.0-13.3; S: 11-13

L: 13.7-14.6; W: 2.6-3.3; inconspicuous striae

Oligotrophic to eutrophic $^{3}$

L: 30.0; W: 9.4;

inconspicuous striae
Meso to supereutrophic conditions in $89 \%$ of samples $(\mathrm{S}, \mathrm{M})$

Eutrophic conditions in $26 \%$ of samples $(\mathrm{S}, \mathrm{M})$

Oligo to super-eutrophic in $70 \%$ of samples (S, M)

Meso to super-eutrophic conditions in $79 \%$ of samples $(\mathrm{S}, \mathrm{M})$

Mesotrophic to super-eutrophic conditions in $37 \%$ of samples $(\mathrm{S}, \mathrm{M})$ Mesotrophic to super-eutrophic conditions in $64 \%$ of samples (S, M) Mesotrophic to eutrophic conditions in $34 \%$ of samples $(\mathrm{S}, \mathrm{M})$

Eutrophic conditions in $41 \%$ of samples (S)

Oligo to mesotrophic conditions in $25 \%$ of samples $(\mathrm{S}, \mathrm{M})$

Oligotrophic to mesotrophic conditions in $21 \%$ of samples $(\mathrm{S})$

Oligotrophic conditions in 36\% of samples (S)

Mesotrophic conditions in 14\% of samples (M)

Mesotrophic to supereutrophic conditions in $46 \%$ of samples $(\mathrm{S}, \mathrm{M})$

Oligo to mesotrophic conditions in $12 \%$ of samples (S)

Oligo to eutrophic conditions in $65 \%$ of samples $(\mathrm{S}, \mathrm{M})$

Oligotrophic conditions in $1 \%$ of samples (S)

Eutrophic $^{1}$ to Oligotrophic to eutrophic conditions in tolerant $^{2}$
$19 \%$ of samples (S. M)

1 van Dam et al. (1994); ${ }^{2}$ Hofmann (1994); ${ }^{3}$ Moro \& Fürstenberger (1997); ${ }^{4}$ Yang \& Dickman (1993); ${ }^{5}$ Potapova \& Charles (2007); ${ }^{6}$ StengerKovacs et al. (2007); ${ }^{7}$ Fontana et al. (2014); - : unavailable information.

*Cyclotella atomus Hustedt, Archiv für Hydrobiologie, Supplement, p. 12, pl. 9, figs. 1-4, 1937.

Figs. 19-21.

D: $6.3-8.0 \mu \mathrm{m}$; $\mathrm{S}: 10-12$ in $10 \mu \mathrm{m}$.
This species differs from $C$. meneghiniana Kützing due to the marginal area with short striae and distinct fultoportulae at every third, fourth or fifth (seldom sixth to seventh) appearing as thicker striae than the others (shadowlines), and the presence of a single, 
Faustino, S.B. et al
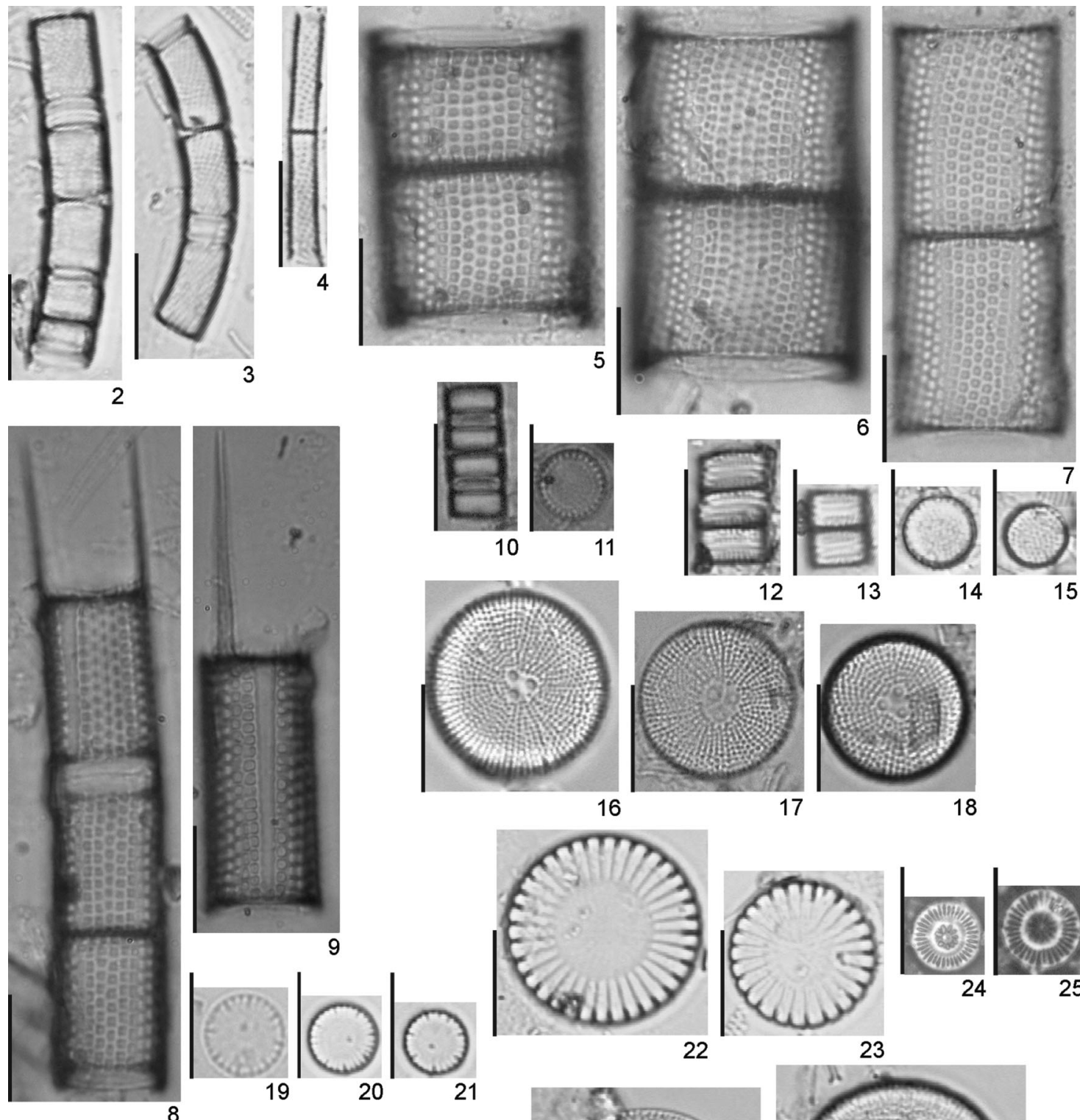

16

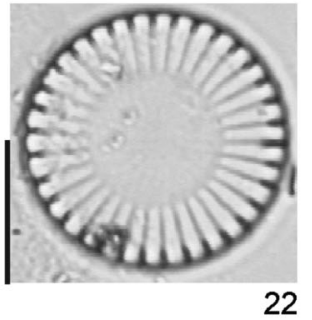

17

18

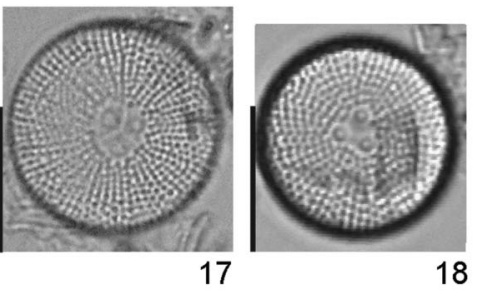

15

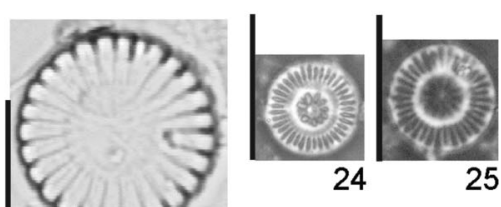

23
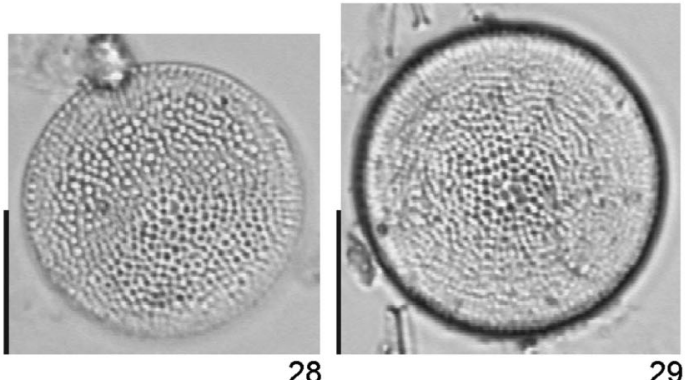

26

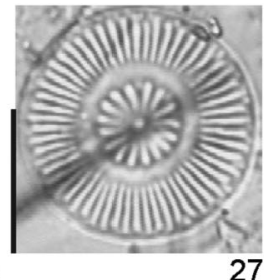

28

29

Figures 2-29. Modern and subfossil diatom flora of Guarapiranga Reservoir. Brazil. 2-3. Aulacoseira ambigua. 4. Aulacoseira granulata var. angustissima. 5-7. Aulacoseira granulata var. australiensis. 8-9. Aulacoseira granulata var. granulata. 10-11. Aulacoseira pusilla. 12-13. Aulacoseira tenella girdle view. 14-15. Aulacoseira tenella valve view. 16-18. Orthoseira roseana. 19-21. Cyclotella atomus. 22-23. Cyclotella meneghiniana. 24-25. Discostella pseudostelligera. 26-27. Discostella stelligera. 28-29. Spicaticribra rudis. Scale bars: $10 \mu \mathrm{m}$.

seldom two, subcentral fultoportulae (Hakansson \& Clarke 1997). Furthermore, $C$. meneghiniana populations can reach larger diameters $(6-35 \mu \mathrm{m})$ than $C$. atomus $(6-10 \mu \mathrm{m})$ (Lowe 1975).

This taxon was probably only reported in Brazil by Moro \& Fürstenberger (1997) and Cavalcante et al. (2013). It is considered a planktonic, acidophilic to alcalinophilic, and a eutrophic species (van Dam et al. 1994, Moro \& Fürstenberger 1997, Kiss et al. 2012). In this study, the species occurred in $79 \%$ of all samples in modern assemblages from mesotrophic to supereutrophic conditions. First report for the state of São Paulo.

\section{Fragilariaceae Greville}

Fragilaria Lyngbye

*Fragilaria crotonensis Kitton, Hardwicke's Sciemce-Gossip 5, p. 109-110, pl. 3, 1869.

Figs. 32-34. 

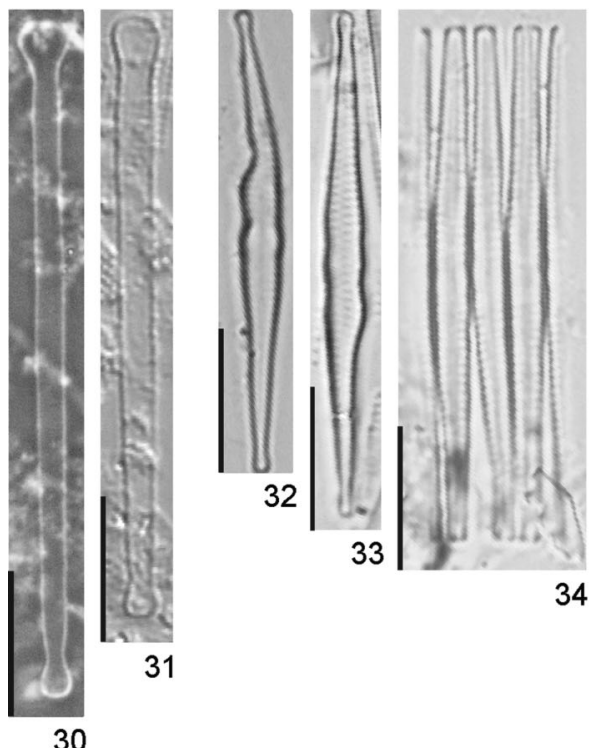

34
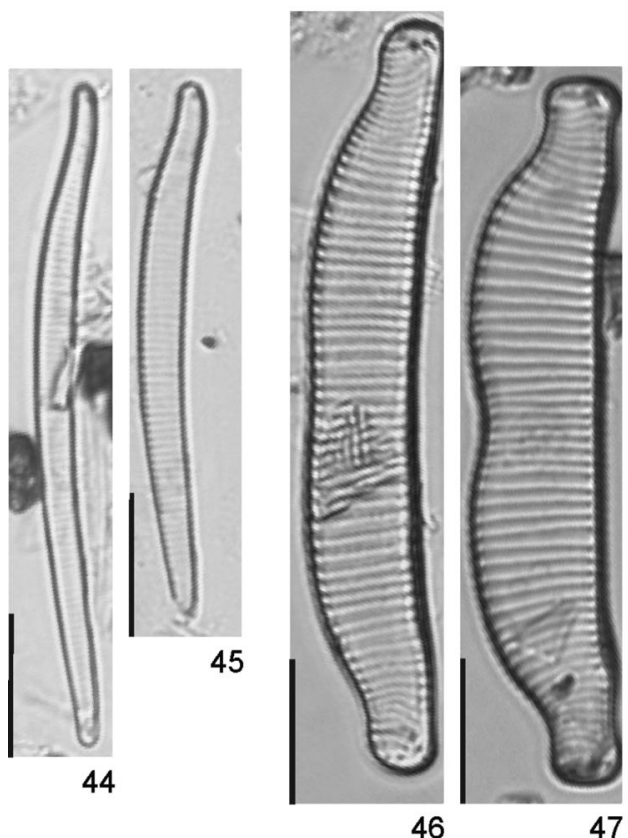
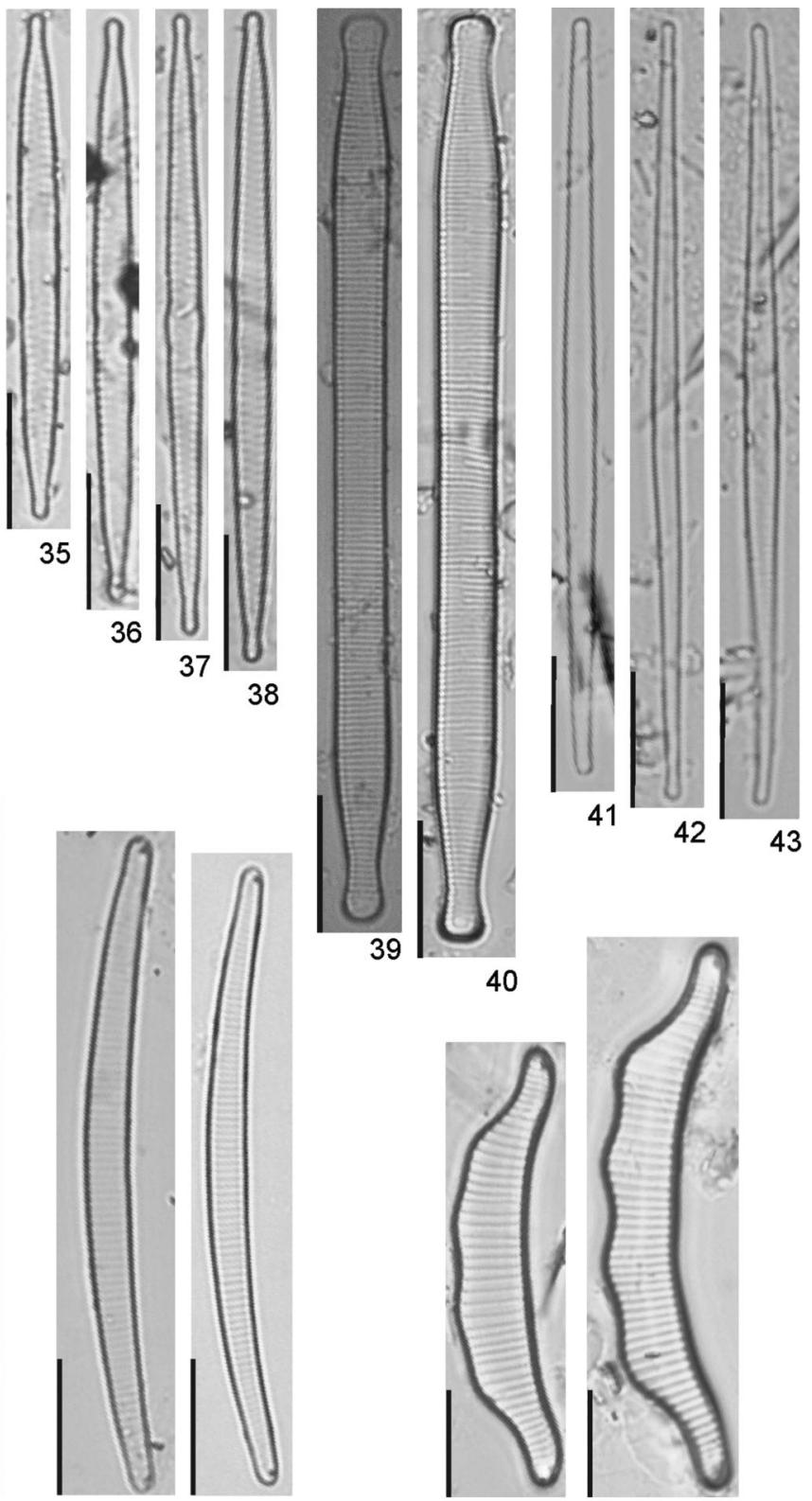

50

51

Figures 30-51. Modern and subfossil diatom flora of Guarapiranga Reservoir. Brazil. 30-31. Asterionella formosa. 32-34. Fragilaria crotonensis. 35-38. Fragilaria fragilarioides. 39-40. Fragilaria rolandschmidtii. 41-43. Fragilaria sp. 1. 44-45. Actinella lange-bertalotii. 46-47. Eunotia bidens. 48-49. Eunotia bilunaris. 50-51. Eunotia camelus. Scale bars: $10 \mu \mathrm{m}$.

L: $32.5-76.6 \mu \mathrm{m}$; W: 2.6-4.0 $\mu \mathrm{m}$; S: 17-19 in $10 \mu \mathrm{m}$.

F. crotonensis forms long raft-like chains, where the cells are joined along the valve faces (Crawford et al. 1985). It is usually found in mesotrophic to eutrophic conditions (van Dam et al. 1994, Hofmann 1994). In this study, the species was well distributed in subfossil and modern assemblages in $81 \%$ of all samples from oligoto eutrophic conditions. Although widely distributed in ecological studies, this is the first taxonomical report for the state of São Paulo.

Fragilaria fragilarioides (Grunow) Cholnoky, Nova Hedwigia 5, p. 168, 1963.

Figs. 35-38.

L: 22.7-48.7 $\mu \mathrm{m}$; W: $2.6-3.3 \mu \mathrm{m} ; \mathrm{S}: 12-16$ in $10 \mu \mathrm{m}$.

This species occurred in $100 \%$ of the modern assemblages in samples ranging from mesotrophic to super-eutrophic conditions.
Fragilaria rolandschmidtii Metzeltin \& Lange-Bertalot, Iconographia Diatomologica 5, p. 236, pl. 1, fig. 14-16, 1998.

Figs. 39-40.

L: $66.1-110.0 \mu \mathrm{m}$; W: $3.6-4.6 \mu \mathrm{m}$; S: $20-22$ in $10 \mu \mathrm{m}$.

This species was proposed from Amazonian material. Metzeltin \& Lange-Bertalot (1998) mentioned its close resemblance with Fragilariforma javanica (Hustedt) Wetzel, Morales \& Ector. It differs by the absence of spines and sternum, two difficult characteristics to observe in LM. This taxon has several features that are distinguished from Fragilaria sensu stricto such as narrow or absent sternum, striae, and apical pore fields, and needs ultrastructural studies to be transferred into to genus Fragilariforma (P.D. Almeida, personal communication in October 2015).

This species has been mistakenly reported in Brazil as F. javanica (e.g. Ferrari \& Ludwig 2007), and this is the first report 
with the correct name. It was distributed in $19 \%$ of all samples from subfossil assemblages from oligo to mesotrophic conditions.

\section{Fragilaria sp. 1}

Figs. 41-43.

Valves linear with weakly convex margin; ends slightly capitated; central area indistinct, bilaterally swelling. L: 53.8-58.7 $\mu \mathrm{m}$; W: 2.0-2.6 $\mu \mathrm{m}$; inconspicuous striae.

This taxon resembles Fragilaria aquaplus Lange-Bertalot \& Ulrich in relation to the valve shape. However, F. aquaplus presents smaller valve dimensions (L: $22-45 \mu \mathrm{m}$; W: 1.5-2.4 $\mu \mathrm{m}$ ) and more capitated apices in smaller individuals (Lange-Bertalot \& Ulrich 2014). Furthermore, additional studies on ultra-structures, such as rimoportulae, are necessary to evaluate if it is a new species. The taxon was commonly reported in modern flora $(64 \%)$ in mesotrophic to eutrophic conditions.

Eunotiaceae Kützing

Actinella Lewis

*Actinella lange-bertalotii Kociolek, Studies on Diatoms 148, pl. 46-50, 99-103, 2001.

Figs. 44-45.

L: $37.0-46.0 \mu \mathrm{m}$; W: 2.4-3.3 $\mu \mathrm{m}$; S: $19-20$ in $10 \mu \mathrm{m}$.

The species was reported in acidic and black waters in the Amazon basin (Melo et al. 2010). It occurred in $21 \%$ of modern assemblage samples in mesotrophic condition. This is the first report for the state of São Paulo.

\section{Eunotia Ehrenberg}

Eunotia bidens Ehrenberg, Abhandlungen der Königlichen Akademie der Wissenschaften zu Berlin, p. 413, figs. 1-4, 1841 (1843). Figs. 46-47.

L: 44.6-53.7 $\mu \mathrm{m}$; W: 8.0-9.0 $\mu \mathrm{m}$ at the swellings, 4.4-5.6 $\mu \mathrm{m}$ at the apices; $\mathrm{S}: 10-11$ in $10 \mu \mathrm{m}$.

Reported in oligo-mesotrophic waters (van Dam et al. 1994). It was presentely well reported ( $41 \%$ samples) in subfossil assemblages during past oligotrophic conditions.

Eunotia bilunaris (Ehrenberg) Schaarschmidt, Magyar Novenytani Lapok 5, p. 159, 261-268, 1881.

Figs. 48-49.

L: 41.2-50.0 $\mu \mathrm{m}$; W: 2.6-3.0 $\mu \mathrm{m}$; S: $19-20$ in $10 \mu \mathrm{m}$.

Tolerant to indifferent (van Dam et al. 1994, Hofmann 1994). It occurred in modern assemblages (21\% of all samples) in mesotrophic waters.

*Eunotia desmogonioides Metzeltin \& Lange-Bertalot, Iconographia Diatomologica 11, p. 27, pl. 5: figs. 1-7, pl. 6: figs. 1-4, 2002 Fig. 52.

L: $115.7-126.5 \mu \mathrm{m}$; W: $4.0-6.0 \mu \mathrm{m}$; $\mathrm{S}: 13-16$ in $10 \mu \mathrm{m}$.

Distributed in $23 \%$ of all samples and only in subfossil assemblage in oligotrophic past conditions. First report for the state of São Paulo.

*Eunotia elephas Ehrenberg, Abhandlungen der Königlichen Akademie der Wissenschaften zu Berlin, p. 414, pl. 1: fig. 5, 1841 (1843).

Fig. 53.

L: $113.5 \mu \mathrm{m}$; W: $25.0 \mu \mathrm{m}$; $\mathrm{S}: 15$ in $10 \mu \mathrm{m}$.

The species was identified based on Ehrenberg's type material available in Metzeltin \& Lange-Bertalot (2007) and Silva et al. (2012). It was scarcely distributed in only $1 \%$ of samples from subfossil assemblages during past oligotrophic conditions with other acidophilic Eunotia species. First report for the state of São Paulo.
*Eunotia metamonodon Lange-Bertalot, Diatoms of Europe 6, p. 153, pl. 217: figs. 1-10, pl. 218: figs. 1-7, 2011.

Fig. 54.

L: $156.6-185.0 \mu \mathrm{m} ; \mathrm{W}: 18.0-19.7 \mu \mathrm{m}$; S: $5-6$ in $10 \mu \mathrm{m}$.

This species is very similar to Eunotia monodon Ehrenberg on the valve outline. However, E. metamonodon usually presents populations with higher dimensions (L: $40.0-250.0 \mu \mathrm{m}, \mathrm{W}: 10.0-$ $15.0 \mu \mathrm{m}$; S: 7-11 in $10 \mu \mathrm{m}$ ) than E. monodon (L: $35.0-90.0 \mu \mathrm{m}, \mathrm{W}$ : 7.0-15.0 $\mu \mathrm{m}$; S: 8-12 in $10 \mu \mathrm{m}$; Patrick \& Reimer 1966).

It occurred in $36 \%$ of all samples from subfossil assemblages during past oligotrophic conditions. First report for the state of São Paulo.

Eunotia monodon Ehrenberg, Abhandlungen der Königlichen Akademie der Wissenschaften zu Berlin, p. 414, pl. 2, fig. 7, 1841 (1843).

Fig. 55.

L: 76.0-88.0 $\mu \mathrm{m}$; W: 7.0-8.0 $\mu \mathrm{m}$; S: $10-11$ in $10 \mu \mathrm{m}$.

Reported in oligotrophic (van Dam et al. 1994) and hypereutrophic waters (Faria et al. 2010). This species was exclusively distributed in $36 \%$ of all samples from subfossil assemblages during past oligotrophic conditions.

*Eunotia cf. paludosa Grunow, Verhandlungen der kaiserlichköniglichen zoologisch-botanischen Gesellschaft in Wien 12, p. 368, pl. 7, 1862.

Figs. 65-66.

Valves weakly arched; ventral margins slightly concave; dorsal margins convex; ends weakly protracted and dorsally reflexed; terminal nodules close to the poles; terminal raphe fissure short. L: 26.9-32.5 $\mu \mathrm{m}$; W: 2.5-3.6 $\mu \mathrm{m}$; S: 16-17 in $10 \mu \mathrm{m}$.

Eunotia paludosa presents higher striae density (E: 18-25 in $10 \mu \mathrm{m}$ ) and more protracted ends (Lange-Bertalot et al. 2011) than the individuals observed in this study. According to these authors, this is an acidophilic species. It was reported in $7 \%$ of samples of subfossil assemblages during past oligotrophic conditions. First report for the state of São Paulo.

Eunotia pseudosudetica Metzeltin, Lange-Bertalot \& García-Rodriguez, Iconographia Diatomologica 15, p. 57, pl. 24, fig. 15-18, 2005. Figs. 58-60.

L: $33.1-45.3 \mu \mathrm{m}$; W: 5.6-6.8 $\mu \mathrm{m}$; $\mathrm{S}: 10-11$ in $10 \mu \mathrm{m}$.

The taxon was reported by Faria et al. (2010) in a hypereutrophic reservoir. In this study, it is well distributed, occurring in $71 \%$ of modern assemblages in samples ranging from meso to supereutrophic conditions.

*Eunotia rabenhorstiana (Grunow) Hustedt var. rabenhorstiana Süßwasser-Diatomeen aus dem Albert National Park in BelgischKongo, p.72, 1949.

Fig. 61.

L: $86.1-127.5 \mu \mathrm{m}$; W: $5.5-5.8 \mu \mathrm{m}$; S: $15-23$ in $10 \mu \mathrm{m}$.

The species occurred in $33 \%$ of all samples and only during past oligotrophic conditions. First report for the state of São Paulo.

*Eunotia rabenhorstii var. triodon Cleve \& Grunow, Synopsis des Diatomées de Belgique, pl. 35, fig. 12A, 1881.

Fig. 64.

L: $20.0-34.2 \mu \mathrm{m}$; W: $5.5-7.9 \mu \mathrm{m}$; $\mathrm{S}: 12-13$ in $10 \mu \mathrm{m}$.

This variety occurs in 17\% of all samples from past oligotrophic conditions. First report for the state of São Paulo.

*Eunotia superbidens Lange-Bertalot, Diatoms of Europe 6, p. 229, pl. 81: figs. 1-10, pl. 82: figs. 1-6, 2011.

Fig. 56-57. 
L: 57.0-67.0 $\mu \mathrm{m}$; W: 11.0-11.7 $\mu \mathrm{m}$ at the swellings, $6.5-10.0 \mu \mathrm{m}$ at the apices; S: $9-11$ in $10 \mu \mathrm{m}$.

It was reported in $41 \%$ of all samples for subfossil assemblages in past oligotrophic conditions. First report for the state of São Paulo.

*Eunotia tridentula Ehrenberg, Abhandlungen der Königlichen Akademie der Wissenschaften zu Berlin, p. 414, pl.2: fig. 14, 1841 (1843).
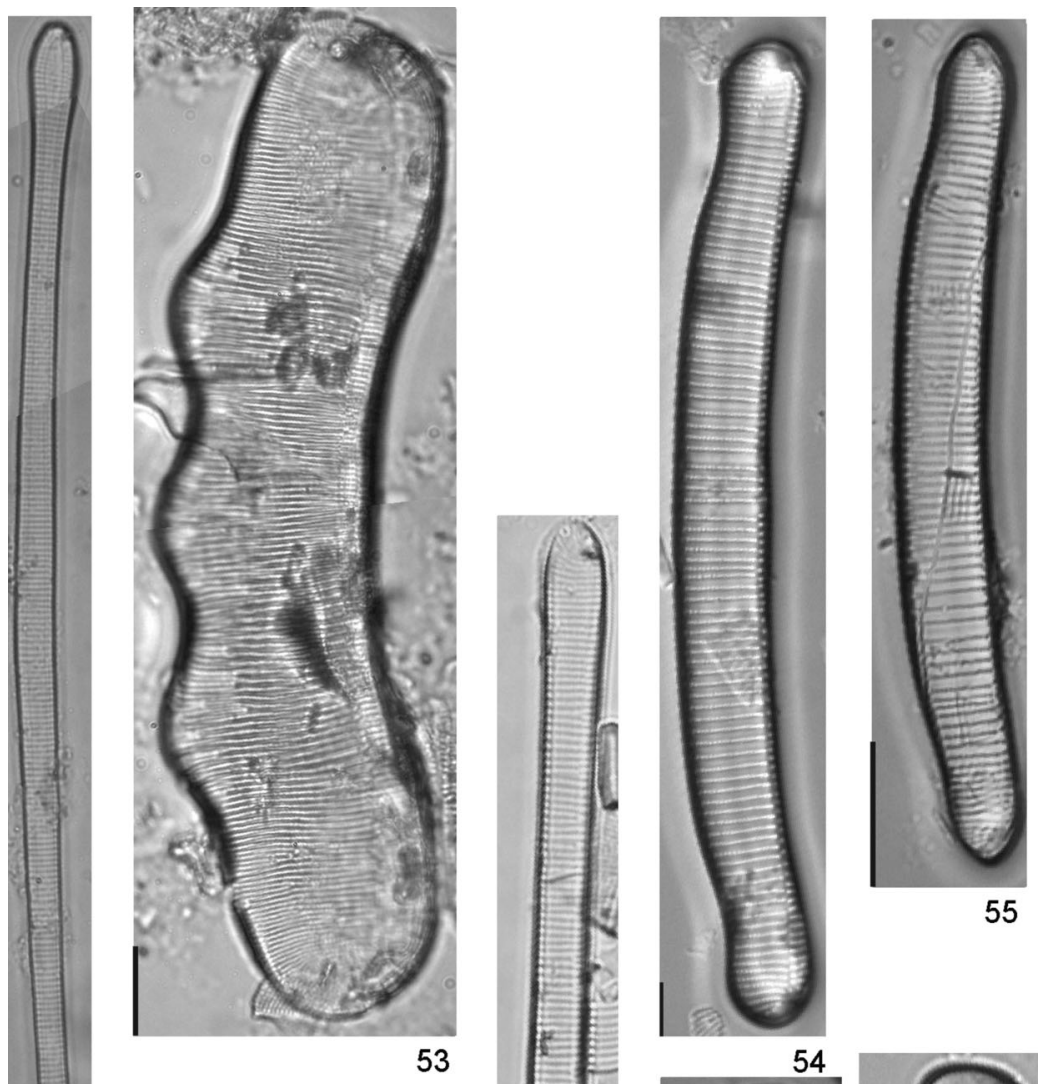

L: $29.6-34.6 \mu \mathrm{m}$; W: $5.8-7.5 \mu \mathrm{m}$; S: $13-18$ in $10 \mu \mathrm{m}$.

The species was found in $9 \%$ of the samples for the subfossil assemblages during past oligotrophic conditions. However, Faria et al. (2010) reported this taxon in a hypereutrophic reservoir. First report for the state of São Paulo.

*Eunotia trigibba Hustedt, Atlas de Diatomaceen-kunde, pl. 286, fig. 16-18, 1913.

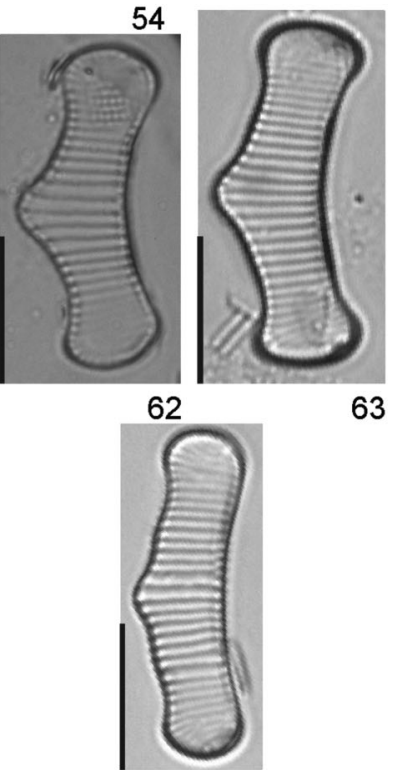

64
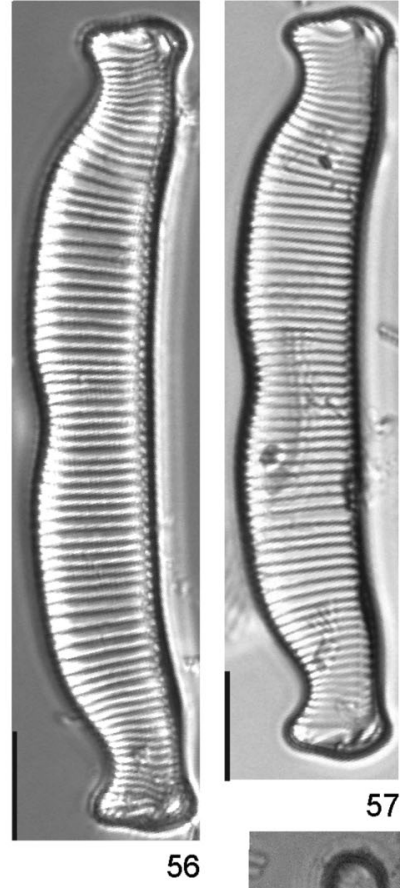

57
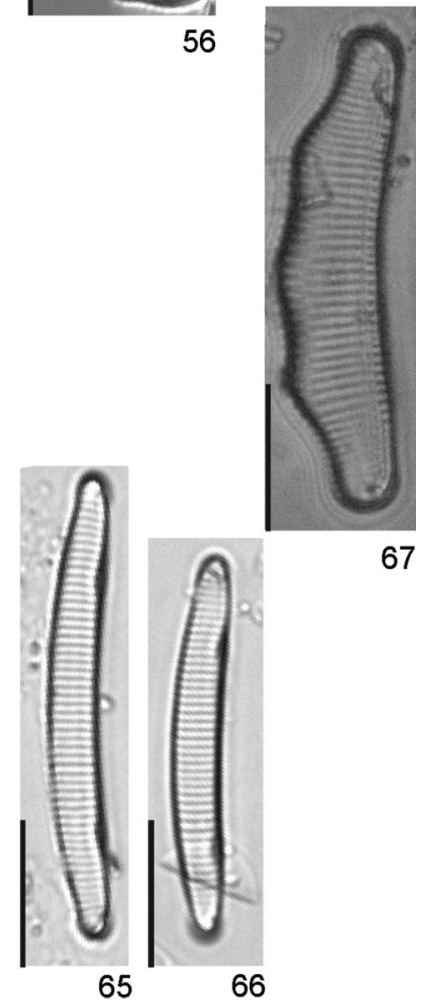

Figures 52-67. Modern and subfossil diatom flora of Guarapiranga Reservoir. Brazil. 52. Eunotia desmogonioides. 53. Eunotia elephas. 54. Eunotia metamonodon. 55. Eunotia monodon. 56-57. Eunotia superbidens. 58-60. Eunotia pseudosudetica. 61. Eunotia rabenhorstiana var. rabenhorstiana. 62-63. Eunotia rabenhorstii var. monodon. 64. Eunotia rabenhorstii var. triodon. 65-66. Eunotia cf. paludosa. 67. Eunotia tridentula. Scale bars: $10 \mu \mathrm{m}$. 
Figs. 68-69.

L: $41.3-46.8 \mu \mathrm{m}$; W: $11.0-13.1 \mu \mathrm{m}$; S: $8-9$ in $10 \mu \mathrm{m}$.

It was reported in $11 \%$ of samples for the subfossil assemblages in past oligotrophic conditions. First report for the state of São Paulo.

*Eunotia tukanorum Wetzel \& D. Bicudo, Nova Hedwigia 91(1-2), p. 58, pls. 173-234 and 253, 2010.

Figs. 71-73.

L: $11.3-28.0 \mu \mathrm{m}$; W: $2.0-2.6 \mu \mathrm{m}$; S: $18-21$ in $10 \mu \mathrm{m}$.
Eunotia tukanorum is a planktonic species proposed by Wetzel et al. (2010) for Negro River (North Brazil), whose waters are generally oligotrophic and characterized by the presence of humic acids due to decomposition of flooded vegetation during the rainy season. In other regions of Brazil, the species has been reported as E. asterionelloides Hustedt in the plankton of oligotrophic and slightly acidic rivers (Laux \& Torgan 2011), and in plankton and periphyton of a pond in the South region (Bicca et al. 2011).

In this study, the species was reported in subfossil assemblages in oligotrophic condition, period characterized by flooded vegetation

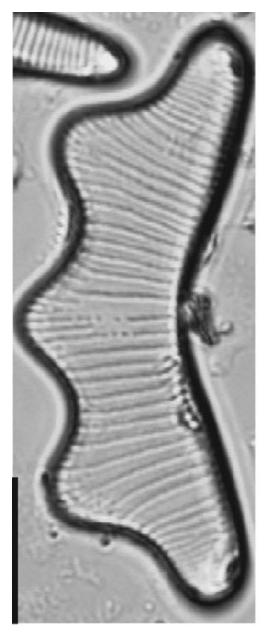

68

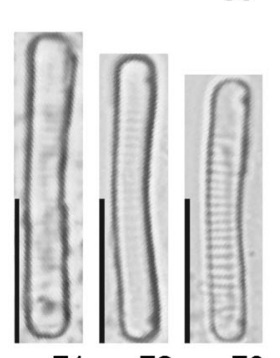

$\begin{array}{lll}71 & 72 \quad 73\end{array}$

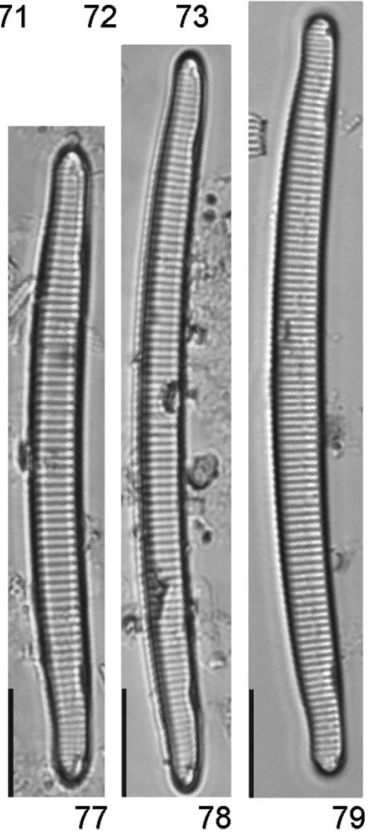

69

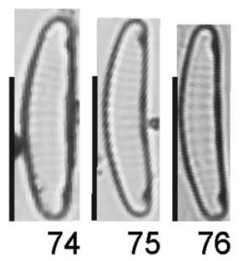

80
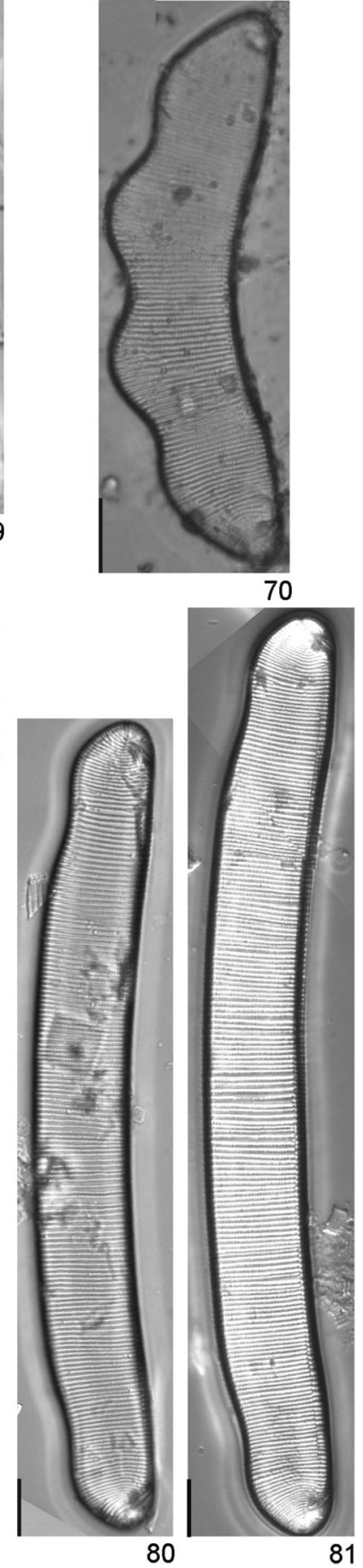

70

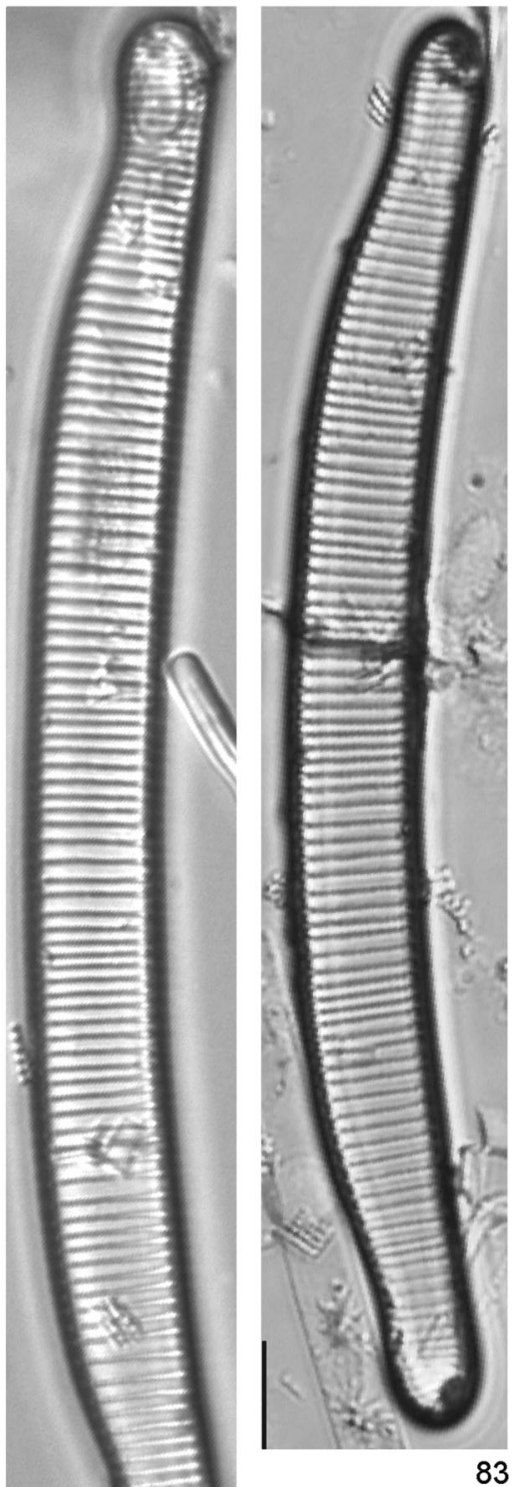

83

Figures 68-83. Modern and subfossil diatom flora of Guarapiranga Reservoir. Brazil. 68-69. Eunotia trigibba. 70. Eunotia zygodon. 71-73. Eunotia tukanorum. 74-76. Eunotia sp.1. 77-79. Eunotia valida. 80-81. Eunotia sp. 2. 82-83. Eunotia sp. 3. Scale bars: $10 \mu \mathrm{m}$. 
during the reservoir construction. Fontana et al. (2014) registered dominance of E. tukanorum during this phase along with the high increase in water discharge associated with the initial use of the reservoir as a public water supply. It was also reported for modern assemblages in mesotrophic conditions. This is a common species in the study area, occurring in $56 \%$ of all samples. So far, the occurrence of this species is restricted to tropical and subtropical regions and seems to be mainly associated with oligotrophic and slightly acidic environments. Although the species was cited in Fontana et al. (2014), this is the first taxonomical register for the state of São Paulo.

*Eunotia valida Hustedt, Die Süsswasser-Flora Mitteleuropas. Heft. 10, 2, p. 178, pl. 229, 1930.

Figs. 77-79.

L: $64.0-92.5 \mu \mathrm{m}$; W: $5.0-6.0 \mu \mathrm{m}$; S: $12-13$ in $10 \mu \mathrm{m}$.

This is a frequent species in Holarctic regions, occasionally occurring in paleo and neotropical regions, and in oligotrophic to dystrophic waters with moderately low $\mathrm{pH}$ and conductivity (Lange-Bertalot et al. 2011). Indeed, this species occurred in 36\% of all samples in subfossil assemblages during past oligothrophic conditions and associated with other acidophilic Eunotia species. This is the species first report in the state of São Paulo.

\section{Eunotia sp. 1}

Figs. 74-76.

Valves slightly arched, ventral margins straight to slightly concave, dorsal margins convex; rounded valve ends, sometimes deflected to the ventral margin; striae parallel; terminal nodule conspicuous and close the poles. L: 13.7-14.6 $\mu \mathrm{m}$; W: 2.5-3.4 $\mu \mathrm{m}$; $\mathrm{S}$ : $13-15$ in $10 \mu \mathrm{m}$.

This taxon resembles two species. However, Eunotia rhomboidea Hustedt often presents heteropolar valves, higher striae density (16-18 in $10 \mu \mathrm{m}$ ) and rhomboid frustules in girdle view (Furey 2011, Furey et al. 2011), and E. botuliformis Wild, Nörpel \& LangeBertalot presents less conspicuous ventral polar nodules, slightly heteropolar valves and higher striae density (15-19 in $10 \mu \mathrm{m}$; LangeBertalot 1993; Silva \& Bicudo 2014). The identification of this taxon depends on further populational studies.

It was distributed in $36 \%$ of all samples mainly in subfossil assemblages from oligotrophic conditions, but also in recent mesotrophic conditions.

\section{Eunotia sp. 2}

Figs. 80-81.

Ventral margin of valves concave, dorsal margin convex; valve ends slightly protracted; striae parallel, slightly spaced; terminal nodule moderately distant from poles. L: $123.0-174.3 \mu \mathrm{m}$; W: 11.4$15.0 \mu \mathrm{m}$; MS: $10-12$ in $10 \mu \mathrm{m}$; AS: $14-15$ in $10 \mu \mathrm{m}$.

This taxon resembles Eunotia indica Grunow in valve outline. However, this species presents a soft inflation in the middle and ends broadly protracted, mostly becoming obliquely wedge-shaped. Furthermore, E. indica presents smaller populations (L: 38.0-100.0 $\mu \mathrm{m}$; W: 8.8-11.0 $\mu \mathrm{m}$; Lange-Bertalot et al. 2011). The taxon was reported in $27 \%$ of samples in subfossil assemblages during past oligotrophic conditions with other acidophilic Eunotia species. It is probably a new species and needs further study.

\section{Eunotia sp. 3}

Figs. 82-83.

Valves slightly arched, dorsal margin convex, ventral margin slightly concave; valve ends rounded to rounded-rostrate; terminal nodule close to apices; striae transapical, parallel throughout valve.

L: $135.7-155.0 \mu \mathrm{m}$; W: $13.0-13.5 \mu \mathrm{m}$; $\mathrm{S}: 7-8$ in $10 \mu \mathrm{m}$.
This taxon resembles Eunotia longicollis Metzeltin \& LangeBertalot in valve shape. However, E. longicollis presents terminal nodule moderately distant from poles and populations with smaller individuals, ranging from 60.0-80.0 $\mu \mathrm{m}$ long, 7.0-7.7 $\mu \mathrm{m}$ width and 8-11 striae in $10 \mu \mathrm{m}$ (Metzeltin \& Lange-Bertalot 1998). It is probably a new species and needs further study.

The taxon was reported in $36 \%$ of all samples in subfossil assemblages in past oligotrophic conditions.

\section{Cymbellaceae Greville}

Encyonema Kützing

Encyonema minutum (Hilse) Mann, The Diatoms: Biology and morphology of the genera, p. 667, 1990 .

Figs. 88-89.

L: 16.9-18.6 $\mu \mathrm{m}$; W: 5.3-6.6 $\mu \mathrm{m}$; S: 9-12 in $10 \mu \mathrm{m}$.

This species is reported in oligo- to mesotrophic conditions (van Dam et al. 1994, Hofmann 1994). However, in this study it occurred in $14 \%$ of samples of modern assemblages and in eutrophic condition.

\section{Gomphonemataceae Kützing}

Gomphonema Ehrenberg

Gomphonema brasiliense Grunow, Naturwissen Beiträge zur Kenntnis der Kaukasusländer, p. 110, pl. 3-4, 1878.

Figs. 92-93.

L: 23.1-27.3 $\mu \mathrm{m}$; W: $6.8-7.3 \mu \mathrm{m}$; $\mathrm{S}: 11-12$ in $10 \mu \mathrm{m}$.

Eutrophic species (van Dam et al. 1994), currently found in $14 \%$ of all samples in recent mesotrophic conditions.

*Gomphonema curvipedatum Kobayasi ex Osada, Atlas of Japanese diatoms based on electron microscopy 1, p. 10, pl. 122, fig. 1-13, 2006.

Figs. 94-96.

L: 25.6-34.6 $\mu \mathrm{m}$; W: 4.4-6.0 $\mu \mathrm{m}$; $\mathrm{S}: 14-16$ in $10 \mu \mathrm{m}$.

This species was previously cited for Brazil and identified as Gomphonema sp. 1 by Silva et al. (2010) and Bertolli et al. (2010). It is characterized by the presence of cuneate and slightly curved apexes, unlike Gomphonema hawaiiense Reichardt, whose apexes are attenuated. The examined population is in agreement with Kobayasi et al. (2006). Ecological information is not available in the literature. Currently, it was found in $14 \%$ of all samples in recent mesotrophic conditions. It is the first report for the the state of São Paulo.

Gomphonema gracile Ehrenberg, Die Infusionsthierchen als vollkommene Organismen, p. 217, pl. 18, fig. 3, 1838.

Figs. 97-98.

L: $43.7-54.6 \mu \mathrm{m}$; W: 6.6-8.6 $\mu \mathrm{m}$; S: $11-14$ in $10 \mu \mathrm{m}$.

Distributed in mesotrophic to eutrophic waters (van Dam et al. 1994, Hofmann 1994). In this study it occurred in only $3 \%$ of all samples from subfossil assemblages in oligo to eutrophic conditions.

Gomphonema lagenula Kützing, Die Kieselschaligen Bacillarien oder Diatomeen, p. 85, pl. 30, fig. 60, 1844.

Figs. 90-91.

L: $16.2-23.2 \mu \mathrm{m}$; W: 5.6-6.0 $\mu \mathrm{m}$; S: 14-16 in $10 \mu \mathrm{m}$.

Present in oligotrophic waters (van Dam et al. 1994). Our findings expand its range distribution, from oligo to eutrophic conditions. It occurred in $27 \%$ of all samples for subfossil and modern assemblages.

*Gomphonema neoapiculatum Lange-Bertalot, Reichardt \& Metzeltin, Iconographia Diatomologica 5, p. 120, pl. 157, figs. 6-9, 1998. Figs. 101-102. 
Faustino, S.B. et al.

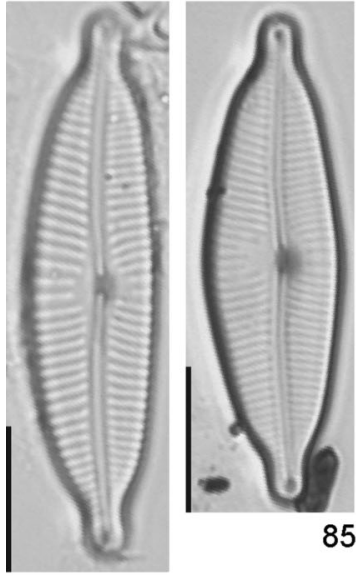

84

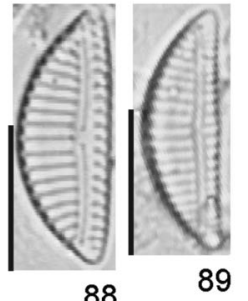

88

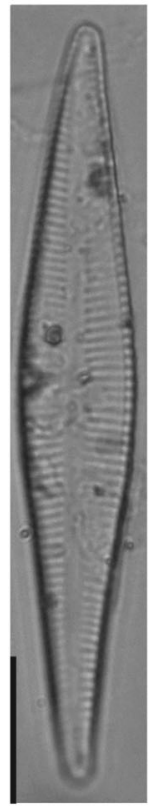

97
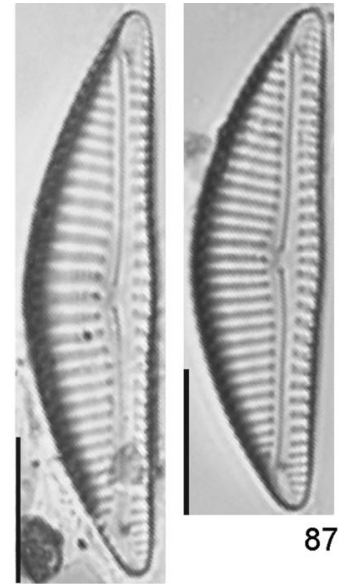

87

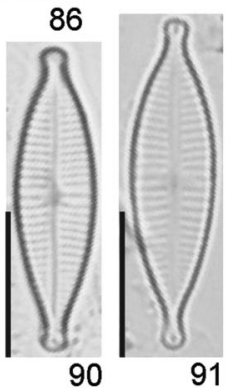

90

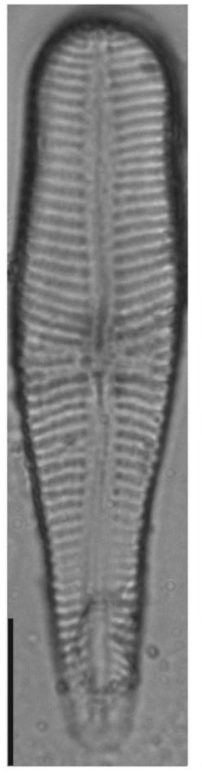

99
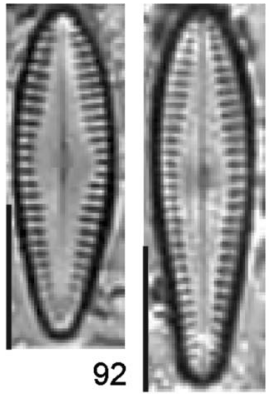

93
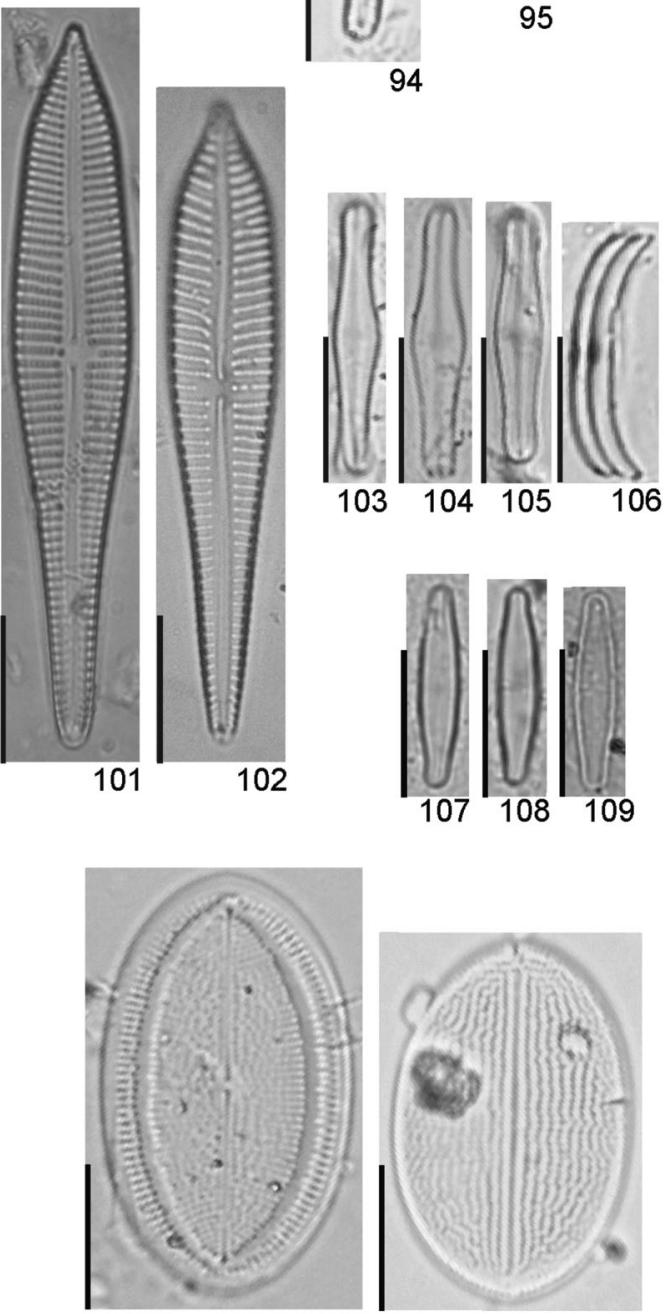

110

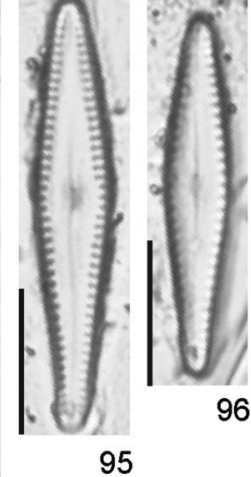

96

95
94
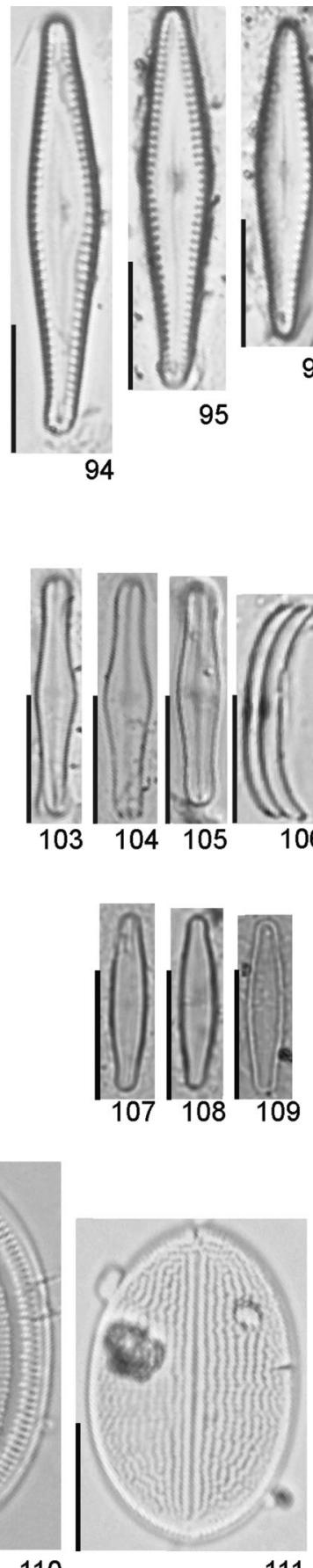

111

Figures 84-111. Modern and subfossil diatom flora of Guarapiranga Reservoir. Brazil. 84-85. Cymbopleura naviculiformis. 86-87. Encyonema silesiacum. 88-89. Encyonema minutum. 90-91. Gomphonema lagenula. 92-93. Gomphonema brasiliense. 94-96. Gomphonema curvipedatum. 97-98. Gomphonema gracile. 99-100. Gomphonema laticollum. 101-102. Gomphonema neoapiculatum. 103-105. Achnanthidium catenatum valve view. 106. Achnanthidium catenatum lateral view. 107-109. Achnanthidium minutissimum. 110. Cocconeis placentula var. lineata. raphe valves. 111. Cocconeis placentula var. lineata rapheless valves. Scale bars: $10 \mu \mathrm{m}$.

L: 44.4-51.2 $\mu \mathrm{m}$; W: 7.5-8.0 $\mu \mathrm{m}$; S: 9-13 in $10 \mu \mathrm{m}$.

According to Metzeltin \& Lange-Bertalot (1998) Gomphonema neoapiculatum has apiculate ends while Gomphonema apicatum Ehrenberg presents rounded-cuneate to slightly apiculate ends.

This species was mistakenly reported as Gomphonema apicatum by Faria et al. (2010) in a hypereutrophic reservoir in the State of Paraná. In this study, it occurred in $14 \%$ of all samples in contemporary eutrophic conditions. Therefore, this is first record in
Brazil with the correct name and the first citation for the State of São Paulo.

\section{Cocconeidaceae Kützing}

Cocconeis Ehrenberg

Cocconeis placentula var. lineata (Ehrenberg) Van Heurck, Synopsis des Diatomées de Belgique, p. 133, 1885.

Fig. 110 raphe valves, Fig. 111 rapheless valves. 
Diatoms from core and surface sediments
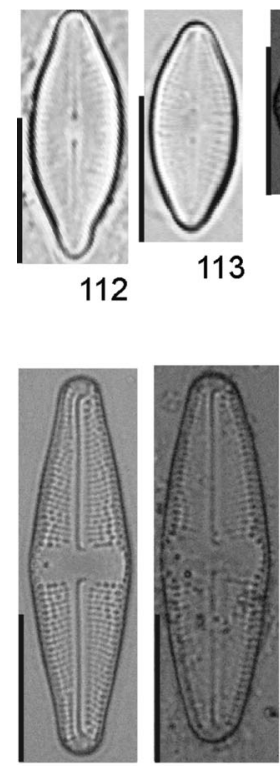

119

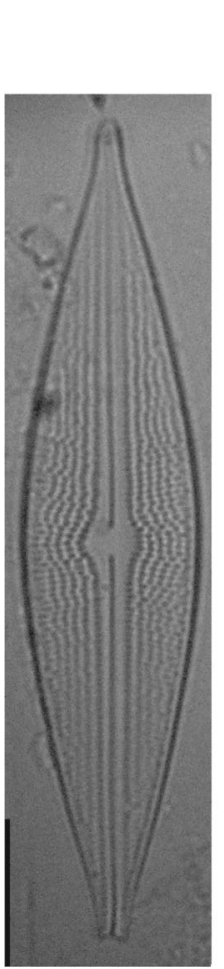

129

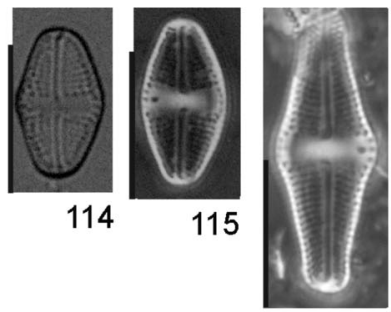

116
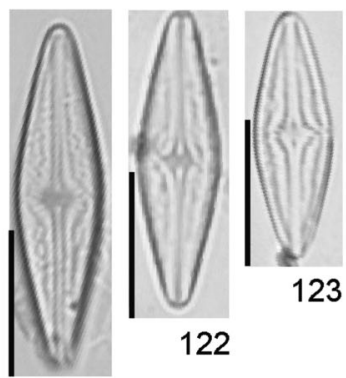

122
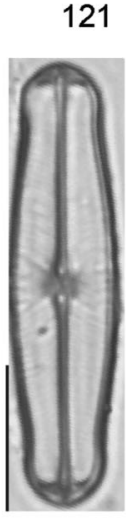

130

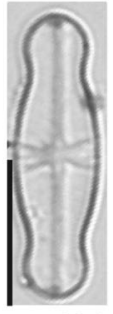

131

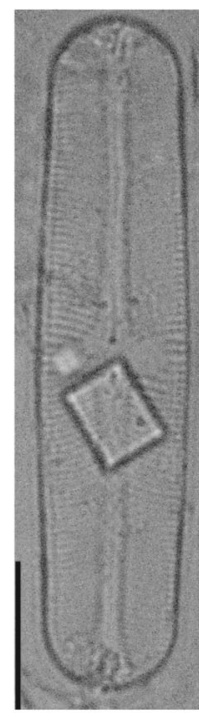

132

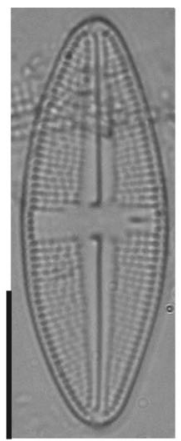

117

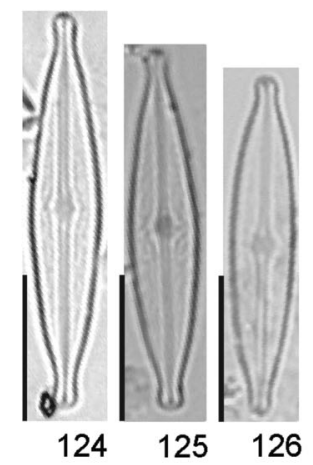

118
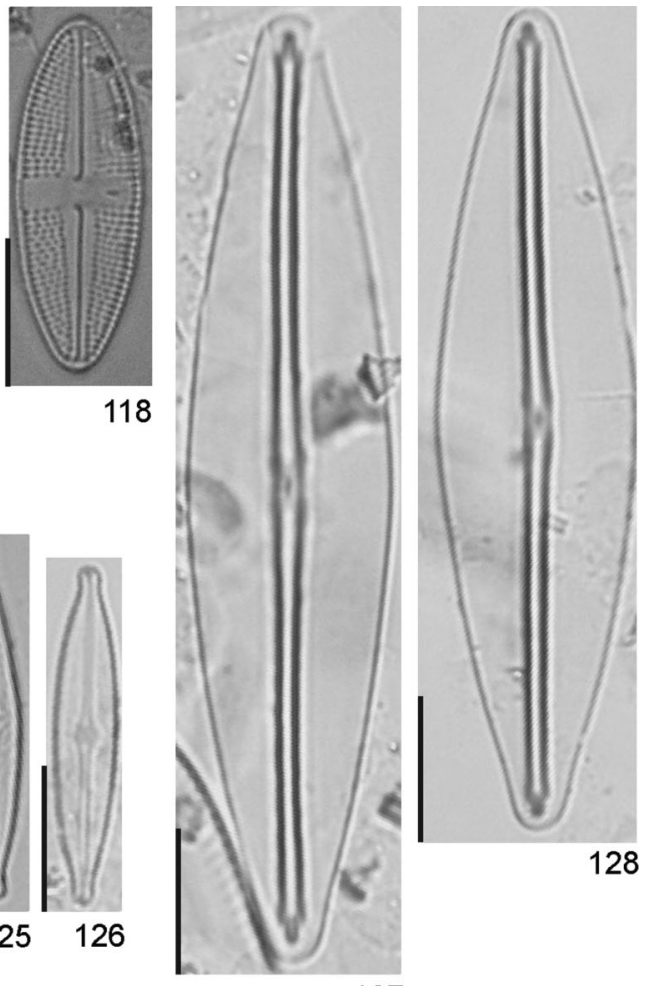

127

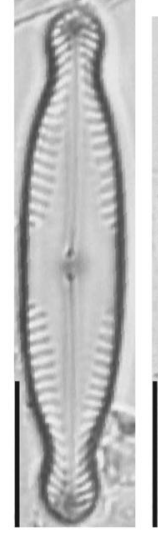

133
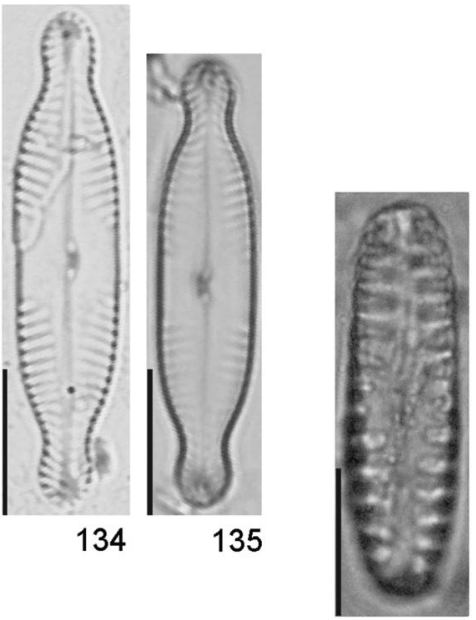

136

Figures 112-136. Modern and subfossil diatom flora of Guarapiranga Reservoir. Brazil. 112-113. Diadesmis confervacea. 114-115. Luticola acidoclinata. 116. Luticola hustedtii. 117-118. Luticola isabelae. 119-120. Luticola simplex. 121-123. Brachysira brebissonii. 124-126. Brachysira microcephala. 127-128. Frustulia saxonica. 129. Brachysira serians var. acuta. 130. Sellaphora capitata. 131. Sellaphora ventraloconfusa. 132. Sellaphora rectangularis. 133-135. Pinnularia brauniana. 136. Pinnularia borealis. Scale bars: $10 \mu \mathrm{m}$.

$\mathrm{L}: 20.6-30.6 \mu \mathrm{m} ; \mathrm{W}: 14.0-18.0 \mu \mathrm{m} ; \mathrm{S}: 18-19$ in $10 \mu \mathrm{m}$ in the raphe valve, $26-28$ in the rapheless valve; A: 20-22 in 10 $\mu \mathrm{m}$ in the raphe valve, $14-16$ in $10 \mu \mathrm{m} \mu \mathrm{m}$ in the rapheless valve.

Ehrenberg (1843) first described the species Cocconeis lineata. Subsequently, based on the similarity between $C$. placentula Ehrenberg var. placentula and C. lineata, Van Heurck (1885) proposed the combination C. placentula var. lineata (Ehrenberg) van Heurck. Recently, Romero \& Jahn (2013) analyzed Ehrenberg's type-material (1843) and complementary culture samples, and concluded that the morphometric differences in valves support the recognition of $C$. lineata. However, according to Potapova \& Spaulding (2013) further studies are necessary to determine whether and how individual species within C. placentula sensu lato may be distinguished using morphological characters. Therefore, we followed AlgaBase (Guiry in Guiry \& Guiry 2016). 
Faustino, S.B. et al
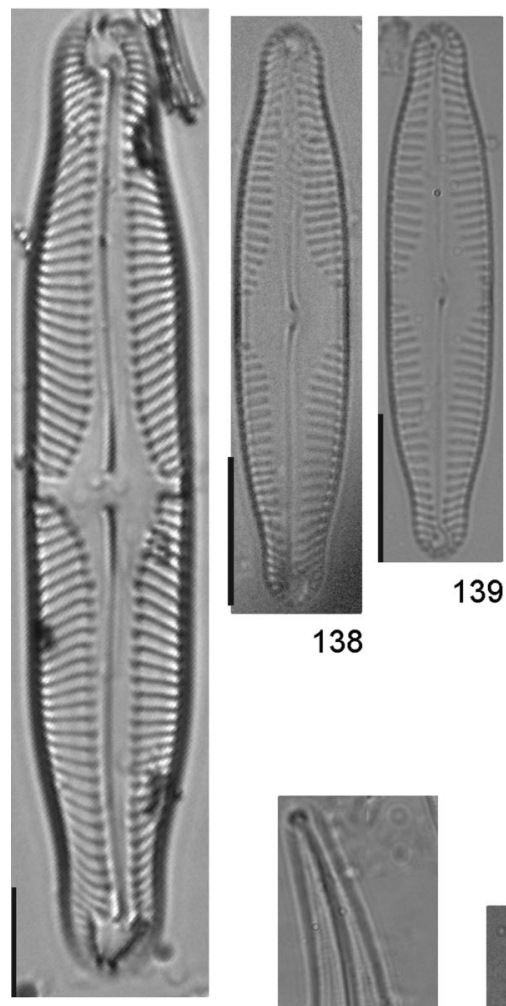

138

137

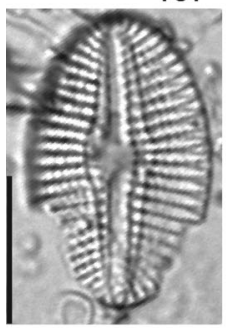

151

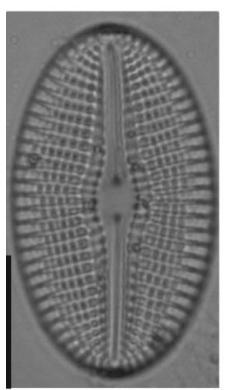

152
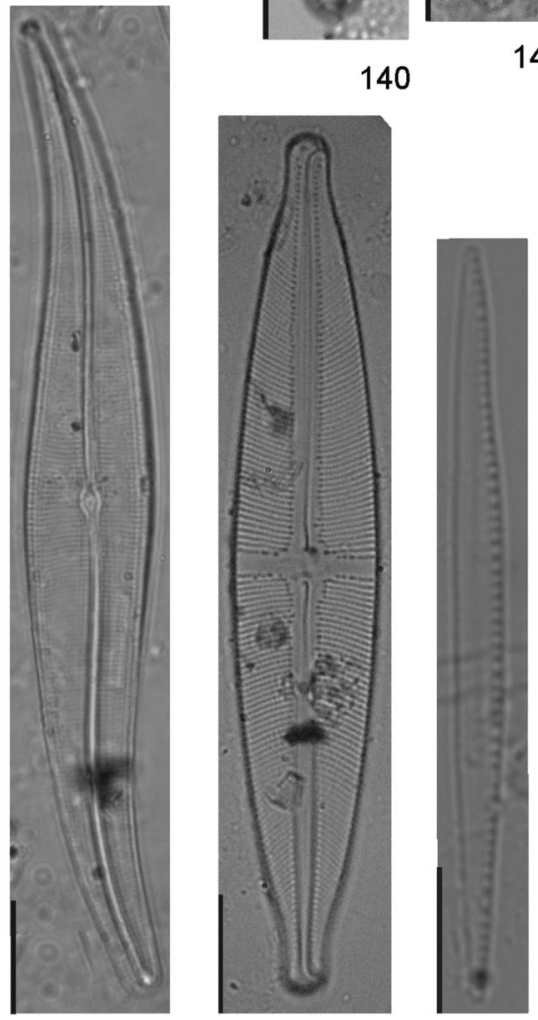

154

155
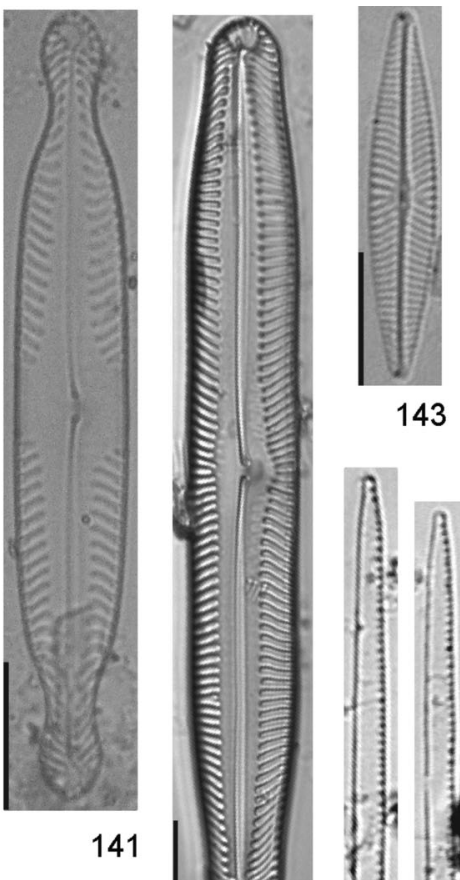

143
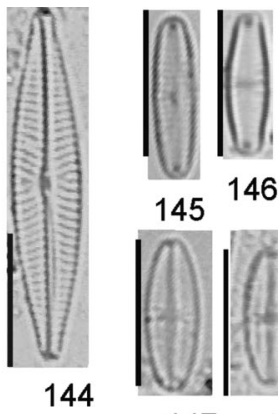

145146
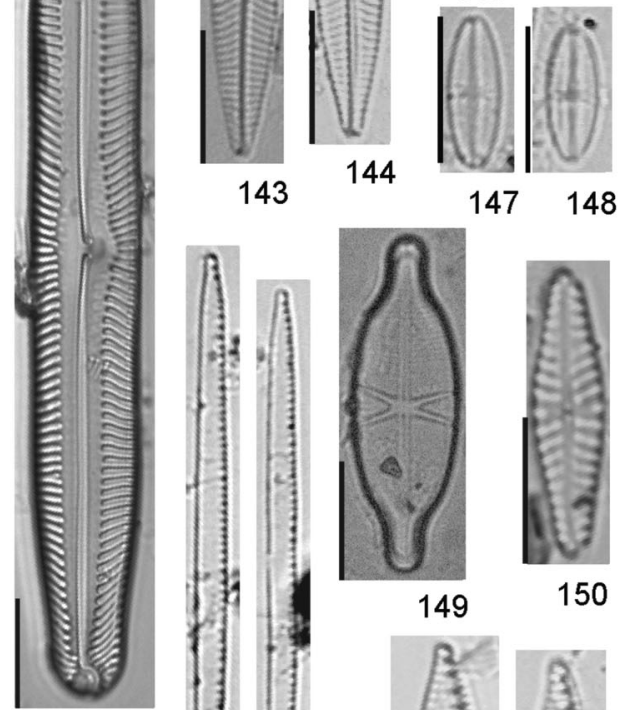

142
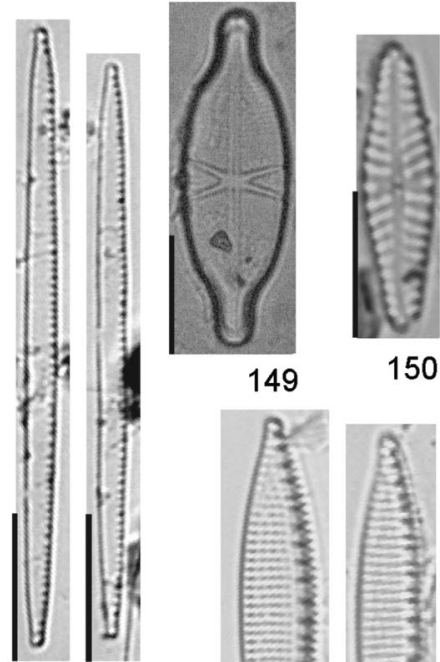

149

150
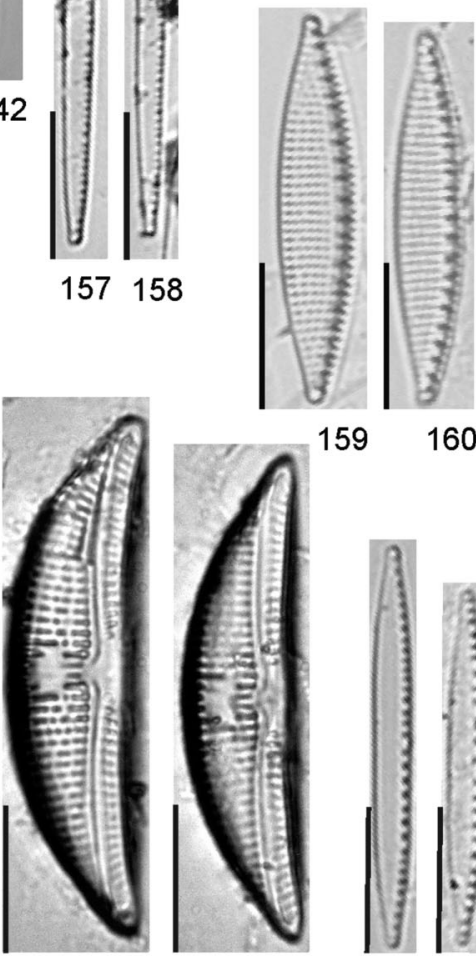

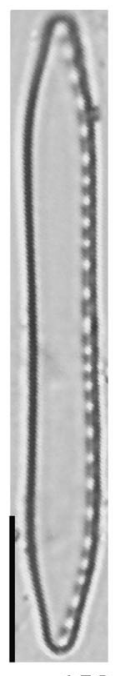

156
159

160

157158

161

162

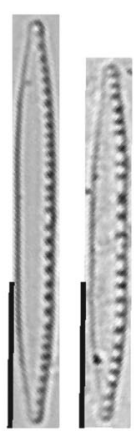

163164

Figures 137-164. Modern and subfossil diatom flora of Guarapiranga Reservoir. Brazil. 137. Pinnularia divergens var. mesoleptiformis. 138-139. Pinnularia subgibba var. lanceolata. 140-141. Pinnularia subanglica. 142. Pinnularia sp. 1. 143-144. Navicula notha. 145-146. Chamaepinnularia submuscicula. 147-148. Eolimna minima. 149. Capartograma crucicula. 150. Hippodonta avittata. 151. Diploneis ovalis. 152. Diploneis subovalis. 153. Gyrosigma acuminatum. 154. Stauroneis acidoclinata. 155. Nitzschia gracilis. 156. Nitzschia terrestris. 157-158. Nitzschia fruticosa. 159-160. Nitzschia amphibia. 161-162. Amphora copulata. 163-164. Nitzschia palea var. debilis. Scale bars: $10 \mu \mathrm{m}$.

This taxon is widely reported in Brazilian literature (as C. placentula var. lineata), suggesting it is a cosmopolitan species. It is common in eutrophic environments (Hofmann 1994, van Dam et al. 1994). In this study, it occurred in $21 \%$ of all samples including past oligotrophic condition and modern meso to eutrophic conditions, suggesting a broader trophic spectrum distribution.
Achnanthidiaceae Mann

Achnanthidium Kützing

Achnanthidium catenatum (Bily \& Marvan) Lange-Bertlot, Iconographia Diatomologica 6, p. 277, 1999.

Fig. 103-105 valve view. Fig. 106 lateral view.

L: 14.4-20.0 $\mu \mathrm{m}$; W: 3.2-3.7 $\mu \mathrm{m}$; inconspicuous striae. 
Achnanthidium catenatum is very similar to Achnanthidium minutissimum Kützing on valve view, but easily recognized in girdle view due to the "C" shaped-valves. Furthermore, A. catenatum presents a widened central portion resulting in an undulated valve margin (Hlúbikova et al. 2011). Bicudo et al. (2009) first registered this species in the state of São Paulo. However, this species was probably previously misidentified as A. minutitimum. Achnanthidium catenatum is an indicator of organic pollution (Berthon et al. 2011). In a paleoreconstruction of eutrophication of a Brazilian reservoir, this species highlighted the onset of a marked eutrophication phase (CostaBöddeker et al. 2012). In the present study, it was very frequent occurring in $71 \%$ of all samples from oligo to eutrophic conditions for subfossil and modern assemblages. Acording to Fontana et al. (2014), this species achived higher abundances during the major cultural eutrophication phase of Guarapiranga Reservoir. Overall, this species is probably an indicator of an environmental shift particularly associated with the eutrophication process.

\section{Diadesmidaceae Mann}

Diadesmis Kützing

Diadesmis confervacea Kützing, Bacillarien oder Diatomeen, p. 109, pl. 30, fig. 8, 1844.

Figs. 112-113.

C: $15.0-18.0 \mu \mathrm{m}$; L: 6.0-6.6 $\mu \mathrm{m}$; S: 22-29 in $10 \mu \mathrm{m}$.

Registered in eutrophic waters (van Dam et al. 1994). Presently, this species had broader distribution from recent mesotrophic to supereutrophic conditions, occurring in $43 \%$ of all samples.

\section{Luticola Mann}

* Luticola acidoclinata Lange-Bertalot, Iconographia Diatomologica 2, p. 76, pl. 24; figs. 24-26, pl. 104, figs. 10-16, 1996.

Figs. 114-115.

L: $10.3-12.0 \mu \mathrm{m}$; W: 6.0-6.6 $\mu \mathrm{m}$; S: 19-23 in $10 \mu \mathrm{m}$; central area surrounded by 4 areolae.

Levkov et al. (2013) provided a thorough discussion of this species' taxonomical problem. The authors considered $L$. intermedia (Hustedt) Levkov, Metzeltin \& Pavlov the most similar species to $L$. acidoclinata and pointed out some subtle differences. In $L$. acidoclinata, the striae has a coarser appearance (8-22 striae in $10 \mu \mathrm{m})$, central area is surrounded by $3-4$ areolae with strongly shortened central striae. L. intermedia presents 22-24 striae in $10 \mu \mathrm{m}$, and central area bordered with 5 areolae. In addition, $L$. acidoclinata inhabits oligotrophic, slightly acidic and cold habitats in temperate zones, while $L$. intermedia occurs in rich waters in tropical/subtropical regions. Presently rare and only registered in $1 \%$ of all samples for subfossil assemblages from oligo to mesotrophic conditions. This is the first citation for the state of São Paulo.

*Luticola hustedtii Levkov, Metzeltin \& Pavlov, Diatoms of Europe 7, p. 131, pl. 24, fig. 49, pl. 166, fig. 24-37, pl. 168, fig. 7-26, pl. 170, fig. 1-7, 2013.

Fig. 116.

L: $19.4 \mu \mathrm{m} ; \mathrm{W}: 6.8 \mu \mathrm{m}$; S: 23 in $10 \mu \mathrm{m}$.

This species might be misidentified as Luticola lagerheimii (Cleve) Mann, since both species have rombic valves expanded in the middle. However, both are easily distinct in their valve size, shape of the central area, position of the stigma and the shape of the areolae (Levkov et al. 2013). The latter authors reported its distribution in several localities from Brazil, Indonesia, Congo,
Tanzania, New Caledonia and Yowa (USA) (Levkov et al. 2013). Presently it was found in only $1 \%$ of all samples during past oligotrophic conditions. This is the first citation for the state of São Paulo.

*Luticola isabelae Metzeltin \& Levkov, Diatoms of Europe 7, p. 140, pl. 106, fig. 6, pl. 108, fig. 1-21, pl. 109, fig. 1-20, 2013.

Figs.117-118.

L: 13.3-28.7 $\mu \mathrm{m}$; W: 6.6-10.0 $\mu \mathrm{m}$; S: 21-24 in $10 \mu \mathrm{m}$.

This species resembles Luticola muticoides (Hustedt) Mann, however the second species has linear-eliptic valves with finaly punctate and higher striae density (26-30 in $10 \mu \mathrm{m}$, Levkov et al. 2013). No ecological information was found. It is a common species occurring in $41 \%$ of all samples only in subfossil assemblages in past oligotrophic conditions. This is the first citation for the state of São Paulo.

*Luticola simplex Metzeltin, Lange-Bertalot \& García-Rodríguez, Iconographia Diatomologica 15, p. 117, pl. 87, fig. 1-9, 2005. Figs. 119-120.

L: $25.6-26.0 \mu \mathrm{m} ; \mathrm{W}: 6.8-8.0 \mu \mathrm{m}$; $\mathrm{S}: 22-23$ in $10 \mu \mathrm{m}$.

Luticola simplex occurs in subtropical regions of South America (Levkov et al. 2013). Ecological information was not found in literature. This study indicates a broad distribution range, occurring in $8 \%$ of all samples from subfossil assemblages (oligotrophic period) and modern assemblages (in eutrophic condition).

\section{Amphipleuraceae Rabenhorst}

Frustulia Rabenhorst

Frustulia saxonica Rabenhorst, Die Algen Sachsens, p. 50, pl. 7, fig. 1, 1853.

Figs. 127-128.

L: 57.5-65.6 $\mu \mathrm{m}$; W: 14.0-14.6 $\mu \mathrm{m}$; inconspicuous striae.

Reported in oligotrophic waters (van Dam et al. 1994). Presently found in $47 \%$ of all samples and for a broader ecological range, including subfossil assemblages for oligotrophic to eutrophic conditions.

\section{Brachysiraceae Mann}

Brachysira Kützing

Brachysira brebissonii Ross, Journal of the Marine Biological Association of the United Kingdom 66(3), p. 607, 1986.

Figs. 121-123.

L: $18.0-24.6 \mu \mathrm{m}$; W: $5.3-6.2 \mu \mathrm{m}$; S: $22-24$ in $10 \mu \mathrm{m}$.

Distributed in oligotrophic waters (van Dam et al. 1994, Hofmann 1994). Presently found in $21 \%$ of all samples in modern mesotrophic condition.

Brachysira microcephala (Grunow) Compère, Bulletin du Jardin Botanique National de Belgique, p. 26, fig. 94, 1986.

Figs. 124-126.

L: 23.7-28.6 $\mu \mathrm{m}$; W: 4.0-5.0 $\mu \mathrm{m}$; inconspicuous striae.

According to Wolfe \& Kling (2001), this species was traditionally named Anomoeoneis vitrea (before the resurrection of Brachysira). However, a detailed study by Compère, in 1988, showed that Navicula microcephala is the earliest available basionym for the diatom equivalent to $A$. vitrea, and thus the correct name within Brachysira is B. microcephala. Furthermore, Lange-Bertalot \& Moser (1994) did not consider Compère's observations of the lectotype for B. microcephala and published another name for the same diatom: $B$. neoexilis 
(Wolfe \& Kling 2001). Therefore, B. microcephala was registered in Brazil as Brachysira vitrea in the state of Paraná (Tavares \& Valente-Moreira 2000; Ludwig et al. 2005) and as B. neoexilis in the state of São Paulo (Silva \& Bicudo 2014).

Brachysira microcephala is a highly polymorphic (ranging from lanceolate to capitate forms) and cosmopolitan diatom distributed in clean and circumneutral to slightly acidic waters (Denys \& Straaten 1992, Wolfe \& Kling 2001). It is commonly found in periphyton and metaphyton worldwide (Czarnecki et al. 1995, Potapova \& Charles 2003, Ibarra et al. 2009), and in pristine environments in paleolimnological studies (Grenier et al. 2006). In the present study it occurred in $42 \%$ of all samples, including subfossil (oligotrophic conditions) and modern assemblages (mesotrophic to eutrophic conditions).

*Brachysira serians var. acuta (Hustedt) Vyverman, Bibliotheca Diatomologica 22, p. 49, pl. 36, figs. 3 a-d, pl. 132, fig D, 1991. Fig. 129.

$\mathrm{L}: 57.5 \mu \mathrm{m} ; \mathrm{W}: 12.5 \mu \mathrm{m}$; $\mathrm{S}: 25$ in $10 \mu \mathrm{m}$.

It differs from the typical variety due to the end shapes, more acute in B. serians var. acuta. Registered in oligotrophic waters by Rodrigues (1984). In this study, var. acuta occurred in $30 \%$ of all samples for subfossil assemblages in past eutrophic conditions. This is the variety's first report for the state of São Paulo.

Sellaphoraceae Mereschkowsky

Sellaphora Mereschkowsky

*Sellaphora capitata Mann \& McDonald, Phycologia 43(4), p. 477, figs 4j-1, figs 38-42, 2004.

Fig. 130

L: $12.3-27.8 \mu \mathrm{m}$; W: $5.2-6.6 \mu \mathrm{m}$; $\mathrm{S}: 18-22$ in $10 \mu \mathrm{m}$; central area: $45-55 \%$ of the valve width.

Sellaphora capitata differs from $S$. pupula (Kützing) Mereschkowsky by presenting subcapitated ends, sinuous raphe, lower striae density $(16-22$ in $10 \mu \mathrm{m})$ that are strongly radiated across the valve surface (Mann et al. 2004). This is a poorly known species in Brazil, and was probably only recorded for the southern region of Brazil by Santos et al. (2011). No ecological information is available. It presently occurred in $21 \%$ of all samples in modern assemblages from mesotrophic to eutrophic conditions. This is the species' first citation for the state of São Paulo.

*Sellaphora rectangularis (Gregory) Lange-Bertalot \& Metzeltin, Iconographia Diatomologica 2, p. 102, pl. 25, figs. 10-12, pl. 125, fig. 7, 1996.

Fig. 132.

$\mathrm{L}: 47.0 \mu \mathrm{m}$; W: $10.6 \mu \mathrm{m}$; S: 17 in $10 \mu \mathrm{m}$; central area: $71 \%$ of the valve width.

Sellaphora rectangularis belongs to the group 'pupula' (Mann et al. 2008), but differs from S. pupula (Kützing) Mereschkovsky by presenting linear elliptical valves, with broadly rounded poles, and parallel valve edge or slightly convex. Can be confused with Sellaphora laevissima (Kützing) Mann, however this has grooves enclosing the raphe system and polar bars absent.

Reported in mesotrophic waters (van Dam et al. 1994). In Brazil this taxon was recorded for the Central-Western (Delgado \& Souza 2007) and Southern regions (Santos et al. 2011). In our data, it was a common species occurring in $44 \%$ of all samples in subfossil assemblages during past oligotrophic conditions. This is the species' first citation for the state of São Paulo.
*Sellaphora ventraloconfusa (Lange-Bertalot) Metzeltin \& LangeBertalot, Iconographia Diatomologica 5, p. 212, 1998.

Fig. 131.

L: 16.1-19.4 $\mu \mathrm{m}$; W: 5.6-5.8 $\mu \mathrm{m}$; inconspicuous estriae; central area: $71 \%$ of the valve width.

The species has probably only been cited by Santos et al. (2011) for the Southern region of Brazil. Ecological information is not available in literature. In the present study, it was registered in $14 \%$ of all samples in recent mesotrophic conditions. This is the species' first report for the state of São Paulo.

\section{Pinnulariaceae Mann}

Pinnularia Ehrenberg

*Pinnularia brauniana (Grunow) Mills, Index of Genera and species of Diatomaceae and their synonyms, p. 1273, 1934.

Figs 133-135.

L: 31.2-36.6 $\mu \mathrm{m}$; W: 6.5-7.3 $\mu \mathrm{m}$; S: $10-13$ in $10 \mu \mathrm{m}$.

Reported in oligotrophic waters (van Dam et al. 1994). In this study, it was registered in $14 \%$ of all samples in recent mesotrophic to eutrophic conditions. This is the species' first register for the state of São Paulo.

Pinnularia borealis Ehrenberg, Abhandlungen der Königlichen Akademie der Wissenschaften zu Berlin, p. 420 (132), pl. $\frac{1}{2}$, fig. 6, pl. 4/1, fig. 5, 1843 .

Fig. 136.

L: 27.5-29.9 $\mu \mathrm{m}$; W: 7.5-8.0 $\mu \mathrm{m}$; $\mathrm{S}: 6-7$ in $10 \mu \mathrm{m}$.

Registered in oligo-mesotrophic waters (Hofmann 1994, van Dam et al. 1994). Presently distributed in 7\% of all samples in past oligotrophic phase of the reservoir.

Pinnularia divergens Smith var. mesoleptiformis Krammer \& Metzeltin, Iconographia Diatomologica 5, p. 170, pl. 173, fig. 1-4, 1998.

Fig. 137.

L: 70.6-74.0 $\mu \mathrm{m}$; W: 11.3-12.0 $\mu \mathrm{m}$; S: 9-11 in $10 \mu \mathrm{m}$.

Pinnularia divergens var. mesoleptiformis differs from the type variety in presenting valves with more pronounced undulations, more linear and subcapitated ends (Frenguelli 1933, Metzeltin \& Lange-Bertalot 1998). This variety is poorly known in Brazil, and was only registered in Southern region by Rocha \& Bicudo (2008). No ecological information was available. It was rare and occurred in only $1 \%$ of all samples in subfossil assemblages in past oligotrophic conditions.

Pinnularia subanglica Krammer, Diatoms of Europe 1, p. 108, 223, pl. 78, fig. 7; pl. 84, fig. 107, 2000.

Figs. 140-141.

L: $53.3-56.6 \mu \mathrm{m}$; W: 5.3-8.6 $\mu \mathrm{m}$; S: 9-11 in $10 \mu \mathrm{m}$.

According to Krammer (2000), this is a benthonic species, with preference for highly oxygenated waters. This species was found in Brazilian planktonic samples (Rocha \& Bicudo 2008). It occurred in $20 \%$ of all samples for subfossil assemblages in past oligotrophic conditions.

Pinnularia subgibba Krammer var. lanceolata Gaiser \& Johanser, Diatom Research 15(1), p. 117, fig. 90-91, 2000.

Figs. 138-139.

L: $37.5-40.6 \mu \mathrm{m}$; W: 7.2-8.1 $\mu \mathrm{m}$; S: $11-13$ in $10 \mu \mathrm{m}$.

Pinnularia subgibba var. lanceolata belongs to the P. gibba Ehrenberg and $P$. gibbiformis Krammer complexes, differing from the first by not having capitated ends and, from the second, by having larger length/width ratio and central area 
with fascia (Gaiser \& Johansen 2000). Rocha \& Bicudo (2008) registered this taxon in the plankton, metaphyton and periphyton in São Paulo, but ecological information was unavailable. In the present study, the taxon was rare, and occurred in $1 \%$ of all samples of subfossil assemblages in the past oligotrophic conditions of the reservoir.

\section{Pinnularia sp. 1}

Fig. 142.

Valves eliptic-lanceolate; margin straight to slightly convex; axial area asymmetric; central area asymmetric, proximal ends in hooked shape, deflected to the same side; robust striae, radiate in the center becoming slight convergent towards the ends. L: $82.6 \mu \mathrm{m}$; W: $10.0 \mu \mathrm{m}$; S: 11 in $10 \mu \mathrm{m}$.

The taxon resembles Pinnularia toscana Krammer, however the later has wider valve $(17.0-20.0 \mu \mathrm{m})$ and bent raphe (Krammer 2000). It occurred in $21 \%$ of all samples for subfossil assemblages only during past oligotrophic conditions.

Chamaepinnularia Lange-Bertalot \& Krammer **Chamaepinnularia submuscicola (Krasske) Lange-Bertalot, Bibliotheca Diatomologica 38, p. 27, pl. 3, fig. 1-4, 1998.

Figs. 145-146.

Valves lanceolate; rounded to attenuate-rounded ends; raphe sternum filiform and narrow; raphe straight; central area slightly lanceolate; striae radiate throughout the entire valve. L: 10.0-11.3 $\mu \mathrm{m}$; W: 2.5-2.8 $\mu \mathrm{m}$; inconspicuous striae.

It differs from Chamaepinnularia mediocris (Krasske) Lange-Bertalot because the second species presents slightly swollen valves in the median portion (Metzeltin \& Witkowski 1996). No ecological information was available in literature. In this study, C. submuscicola was found in 7\% of all samples in recent mesotrophic conditions. This is the first report of species for Brazil.

Diploneidaceae Mann

Diploneis (Ehrenberg) Cleve

Diploneis ovalis (Hilse) Cleve, Acta Societatia pro Fauna et Flora Fennica 8(2), p. 44, pl. 2, 1891.

Fig. 151.

L: $21.3 \mu \mathrm{m}$; W: $13.1 \mu \mathrm{m}$; S: 11 in $10 \mu \mathrm{m}$; A: 16 in $10 \mu \mathrm{m}$.

Registered in oligotrophic waters (van Dam et al. 1994, Hofmann 1994). It was sparsely distributed occurring in $1 \%$ of all samples in past oligotrophic conditions.

Diploneis subovalis Cleve, Kongliga Svenska Vetenskapsakademiens Handlingar, Series 4 26(2), p. 96, pl. 1, fig. 27, 1894. Fig. 152.

L: $27.5 \mu \mathrm{m}$; W: $15.5 \mu \mathrm{m}$; S: 11 in $10 \mu \mathrm{m} ; 16$ in $10 \mu \mathrm{m}$.

No ecological information was found. It was rare, occurring in $1 \%$ of all samples in past oligotrophic conditions.

\section{Naviculaceae Kützing \\ Navicula Bory}

Navicula notha Wallace, Notulae Naturae Bacillarien order Diatomeen, p. 4, pl. 1, figs. 4A-D, 1960.

Figs. 143-144.

L: 26.9-43.3 $\mu \mathrm{m}$; W: $5.0-7.3 \mu \mathrm{m}$; S: $14-17$ in $10 \mu \mathrm{m}$.

Distributed in oligotrophic to mesotrophic waters (van Dam et al. 1994). In this study, it occurred in $33 \%$ of all samples in all trophic state gradients in subfossil and modern assemblages.

Eolimna Lange-Bertalot \& Schiller
Eolimna minima (Grunow in Van Heurck) Lange-Bertalot \& Schiller, Bibliotheca Diatomologica 38, p. 153, 1998.

Figs. 147-148.

L: 8.6-10.6 $\mu \mathrm{m}$; W: 3.4-4.0 $\mu \mathrm{m}$; inconspicuous striae.

Eutrophic to tolerant species (van Dam et al. 1994, Hofmann 1994). The species was found in $43 \%$ of all samples of modern assemblages from mesotrophic to eutrophic conditions.

Hippodonta Lange-Bertalot, Witkowski \& Metzeltin *Hippodonta avittata (Cholnoky) Lange-Bertalot, Metzeltin \& Witkowski, Iconographia Diatomologica 4, p. 253, pl. 1, figs. 3034, 1996.

Fig. 150 .

L: $17.6-20.3 \mu \mathrm{m}$; W: $5.0-5.3 \mu \mathrm{m}$; S: $10-12$ in $10 \mu \mathrm{m}$.

Species reported in mesotrophic to eutrophic waters (van Dam et al. 1994). It was found in $14 \%$ of all samples of modern assemblages in mesotrophic conditions. This is the species' first citation for the state of São Paulo.

Pleurosigmataceae

Gyrosigma Hassall

*Gyrosigma acuminatum (Kützing) Rabenhorst, Die Süsswasser-Diatomaceen (Bacillarien.): für Freunde der Mikroskopie, p. 47, pl. 5, fig. 5a, 1853.

Fig. 153.

L: $82.8 \mu \mathrm{m}$; W: $10.7 \mu \mathrm{m}$; inconspicuous striae.

Reported in eutrophic waters (Luchini \& Verona 1972). Our data expanded its distribution for oligotrophic conditions. It was found in $7 \%$ of all samples in past oligotrophic phase of the reservoir. Although cited in ecological studies, this is the species' first taxonomical citation for the state of São Paulo.

\section{Stauroneidaceae Mann}

\section{Stauroneis Ehrenberg}

**Stauroneis acidoclinata Lange-Bertalot \& Werum, Iconographia Diatomologica 13, p. 173, pl. 42, figs. 1-12, 2004.

Fig. 154.

Valves linear-lanceolate; subcapitate ends; proximal ends of the raphe slightly curved to the same side; axial area linear; central broad area with stauros slightly larger near valve margin; striae radiate and absent in the stauro. L: 69.8-73.8 $\mu \mathrm{m}$; $\mathrm{W}: 12.0-12.3 \mu \mathrm{m}$; S: $19-20$ in $10 \mu \mathrm{m}$; A: $23-25$ in $10 \mu \mathrm{m}$.

The studied population presented larger valves dimensions and lower striae density than proposed in Werun \& LangeBertalot (2004; L: 35-60 $\mu \mathrm{m}$; W: 8.5-10.5 $\mu \mathrm{m}, 25-30$ striae in $10 \mu \mathrm{m})$. According to these authors, $S$. acidoclinata was found in a fountain in Germany with low conductivity water, associated with acidophilic Eunotia species. Further ecological information was not found. In this study, the species also occurred with other abundant Eunotia species and in $24 \%$ of all samples during past oligotrophic phase of the reservoir. First citation for Brazil.

\section{Bacillariaceae Ehrenberg}

Nitzschia Hassall

Nitzschia amphibia Grunow, Verhandlungen der kaiserlichköniglichen zoologisch-botanischen Gesellschaft in Wien 12, p. 574, pl. 12, fig. 23, 1862.

Figs. 159-160.

L: $17.3-28.0 \mu \mathrm{m}$; W: 4.4-6.0 $\mu \mathrm{m}$; S: 15-16; F: 9-10 in $10 \mu \mathrm{m}$.

Considered a eutrophic species (van Dam et al. 1994). Our data reported the species in $25 \%$ of all samples of modern assemblages from mesotrophic to super-eutrophic conditions. 
*Nitzschia fruticosa Hustedt, Die Diatomeenflora des Flußsystems der Weser im Gebiet der Hansestadt Bremen 34(3), 349, pl. 1, 1957. Figs. 157-158.

L: 40.3-44.0 $\mu \mathrm{m}$; W: 1.9-2.2 $\mu \mathrm{m}$; inconspicuous striae; F: 15-17 in $10 \mu \mathrm{m}$.

Nitzschia fruticosa Hustedt is characterized by the presence of stellate colonies. Although no colonies were found in sediment samples, further analyses of planktonic materials showed typical stellate colonies, allowing its identification.

Nitzschia fruticosa was registered in Brazil for planktonic samples in pond and rivers in southern Brazil (Moro \& Fürstenberger 1993, Laux \& Torgan 2011). No ecological information was available in literature. In the present study, the species was reported in 59\% of all samples for subfossil assemblages in a broad environmental range from past oligotrophic to eutrophic conditions, although mainly in the eutrophic phase. This is the first taxonomical report of the species in the state of São Paulo.

Nitzschia gracilis Hantzsch ex Rabenhorst, Hedwigia 2, p. 40, pl. 6, fig. 8, 1860.

Fig. 155.

L: 51.2-52.2 $\mu \mathrm{m} ; \mathrm{W}: 2.8-3.4 \mu \mathrm{m}$; inconspicuous striae; F: 9-11 in $10 \mu \mathrm{m}$.
Distributed in mesotrophic to eutrophic waters (van Dam et al. 1994). It occurred in modern assemblages in $36 \%$ of all samples from eutrophic to super-eutrophic conditions.

Nitzschia palea var. debilis (Kützing) Grunow, Beiträge zur Kenntniss der Arctischen Diatomeen. Kongliga Svenska-Vetenskaps Akademiens Handlingar 17(2), p. 96, 1880.

Figs. 163-164.

L: 22.0-28.4 $\mu \mathrm{m}$; W: 2.0-2.6 $\mu \mathrm{m}$; inconspicuous striae; F: 9-11 in $10 \mu \mathrm{m}$.

No ecological information was found. The species was widespread in modern assemblages, occurring in $93 \%$ of all samples in mesotrophic to supereutrophic conditions.

*Nitzschia terrestris (Petersen) Hustedt, Abhandlungen der Königlichen Akademie der Wissenschaften zu Berlin 8(9), p. 386, 1934. Fig. 156.

$\mathrm{L}: 19.0-45.0 \mu \mathrm{m}$; $\mathrm{W}: 4.2-5.0 \mu \mathrm{m}$; inconspicuous striae; F: 6-10 in $10 \mu \mathrm{m}$.

This species is not well known in Brazil, and was registered in the periphyton by Santos et al. (2011). Ecological information was not found. Currently, the species occurred in $30 \%$ of all samples in subfossil assemblages in past oligotrophic phase of the reservoir and in modern assemblages in mesotrophic conditions. Although
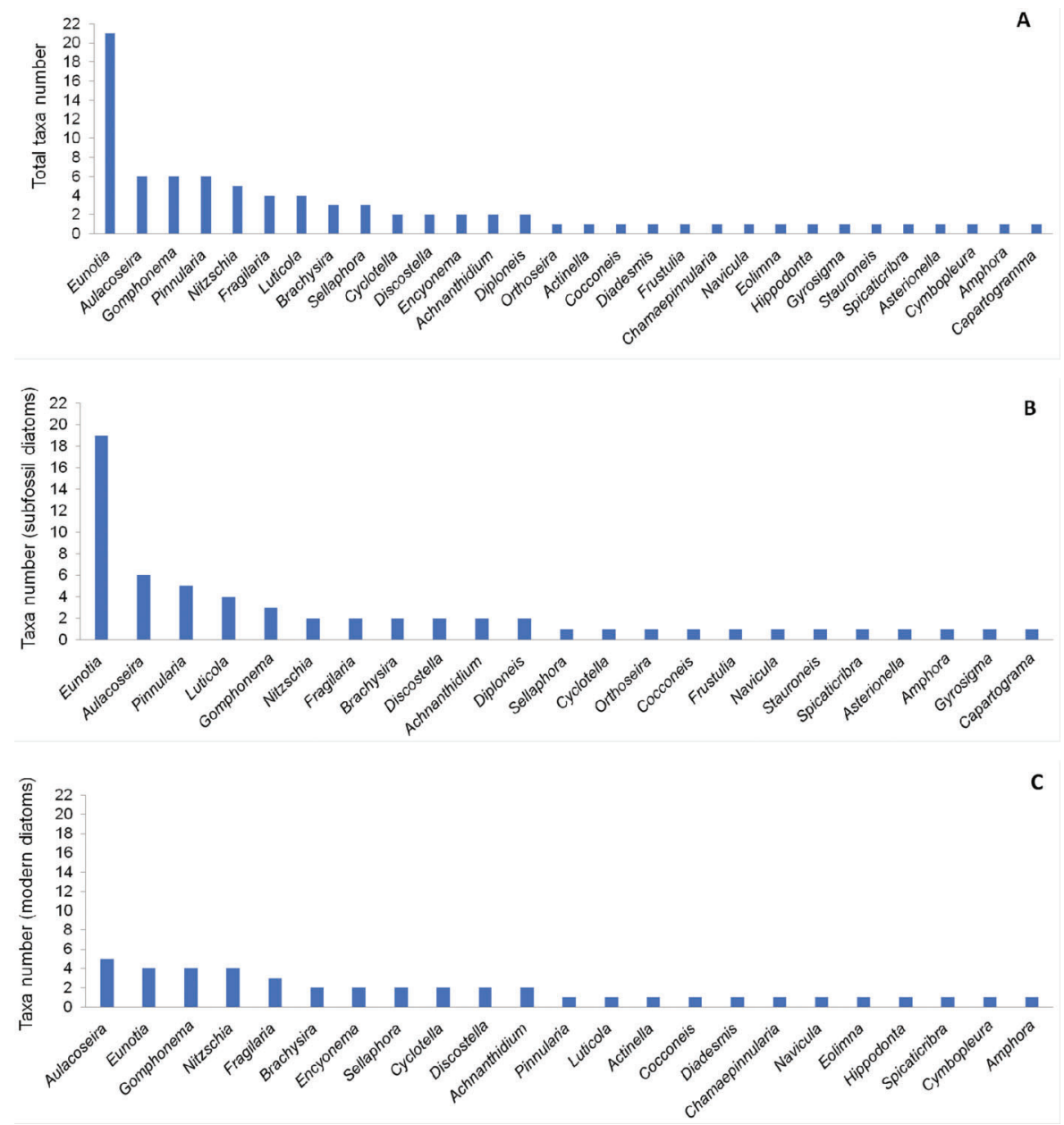

Figure 165. Taxa number per genera in Guarapiranga Reservoir. (A) for both subfossil and modern diatom assemblages; (B) for subfossil diatom (core sediment) assemblage; (C) for modern diatom assemblage (surface sediment). 


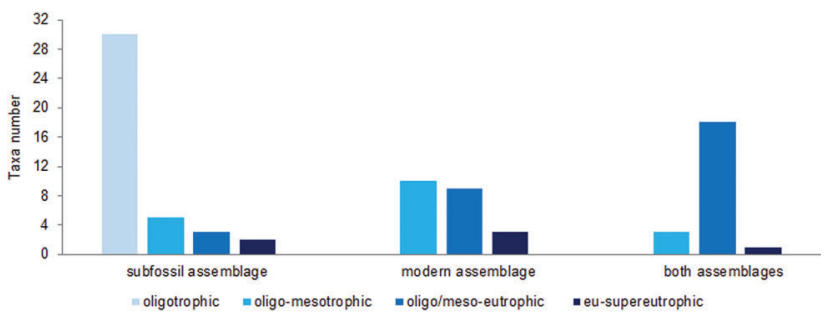

Figure 166. Taxa number according to trophic state gradient exclusively found in subfossil assemblages, modern assemblages and in both assemblages.

the species was cited in a paleolimnological study (Costa-Böddeker et al. 2012), this is the first taxonomical report for the state of São Paulo.

\section{Richness and eutrophication gradient}

The subfossil and modern diatom flora of Guarapiranga comprised 84 infrageneric taxa from which $47.6 \%$ were exclusively from the subfossil assemblages. Eunotia was by far the most represented genus in species number, reaching a 3.5 times greater number than the second ranking genera Aulacoseira, Gomphonema and Pinnularia (Figure 165A), and this trend was mostly accounted by the distribution of subfossil diatoms (Figure 165B). Eunotia was mainly found during the initial oligotrophic phase of the reservoir (ca. 1919-1932), characterized by flooded vegetation (Atlantic Forest) for the reservoir construction. This early phase probably had a wellilluminated water column, oligotrophic and acidic waters due to the dissolved humic substances originated from the decomposition of vegetation (Fontana et al. 2014), favouring this commonly benthic/periphytic genus usually abundant in acidic oligotrophic waters (Krammer \& Lange-Bertalot 1991, van Dam et al. 1994, Wetzel et al. 2010, Lange-Bertalot et al. 2011). Differently, modern assemblages presented the species number more uniformly distributed among the genera (Figure 165C).

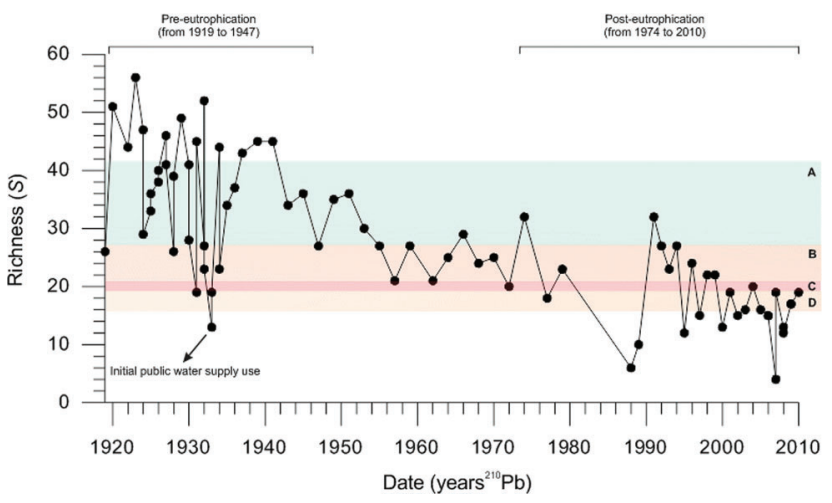

Figure 167. Diatom species richness recorded over 90 years (subfossil assemblage) and in modern assemblages in surface sediments (colored horizontal zones) of the Guarapiranga Reservoir. Brackets indicate past limnological phases. For modern assemblages - A: richness under contemporary mesotrophic conditions (sites 01 to 05 ), B: richness in eutrophic conditions (sites 06 to 11 ), C: richness in supereutrophic conditions (site 12), D: richness under eutrophic conditions (sites 13-14).
Concerning diatom distribution according to trophic state range (Figure 166), the species number for the oligotrophic condition was markedly higher in the subfossil assemblages, where this phase was uniquely represented in Guarapiranga Reservoir. Furthermore, a decline in the total species number along the trophic state gradient was observed for subfossil and modern assemblages (Figure 166). This pattern was even clearer when considering the changes in species richness (number of species per sample) over time following trophic state changes in the reservoir (Figure 167). Thus, during preeutrophication period (up to ca. 1947), richness presented high values, achieving its highest figure over time and space in the reservoir history. However, a marked decline occurred around 1933 associated with physical and hydrological impacts when started the use of the reservoir as a public water supply and the water discharge had a seven-fold increase (Fontana et al. 2014). According to these authors, this change led to dominance of Eunotia tukanorum, a typical planktonic species of the genus, and disappearance of benthic species. During the transitional period with moderate cultural eutrophication (ca. 1947-1974) richness gradually declined. With the onset of eutrophication in the 1970s (Fontana et al. 2014) until 1990 there was a drastic decline in richness and the replacement of oligotrophic to eutrophic species mainly Aulacoseira granulata var. granulata, Cyclotella meneghiniana and Nitzschia fruticosa (Fontana et al. 2014). The major eutrophication period occurred particularly after ca. 1990 (Fontana et al. 2014) when an unexpected increase in richness was observed. During this period, population rapidly increased in drainage basin with expansion of slum dwellings without adequate sewage treatment (Whately \& Cunha 2006). Consequently, gastroenteritis infection in local population became frequent and the agency in charge of the public water supply started using copper sulphate in 1991 to control cyanobacterial blooms (Beyruth 2000). The sudden increase in richness was very probably associated with the control of cyanobacterial dominance and the abrupt opening of new resources for other algal assemblages, including diatoms. With the intensification of urbanization and eutrophication, richness continued declining over time. Considering the space gradient, richness in modern assemblages never achieved values corresponding to the oligotrophic phase of subfossil assemblages although higher values were also achieved in contemporary mesotrophic conditions of the upstream sites 01 to 05 (Fig. 167A). Towards downstream richness decreased along the trophic state gradient (Figs. 167B, C, D).

Overall, the change in richness from oligotrophic to supereutrophic phases led to a sharp reduction of the oligotrophic species, which represented $23 \%$ of the total number of diatom species in the reservoir mainly represented by Eunotia ( 15 species and probably 3 new species). Losses in algal biodiversity due to cultural eutrophication has been scarcely reported in Brazil (e.g. Crossetti et al. 2008) given the paucity of long-term monitoring data, and the lack of information before the onset of eutrophication. In this regard, the statement by Davidson et al. (2013) that our understanding of the relationship between anthropogenic impacts and lake biodiversity changes is typically based on contemporary data sets and space-for-time substitution holds true for Brazilian ecosystems. Therephore, in many cases paleolimnological approach can offer a unique tool to assess biodiversity changes encompassing time scales relevant to human-induced degradation and since pre-anthropogenic impacts. 


\section{Final remarks}

This survey encompassing subfossil diatom (ca. 90 years) and modern assemblages in surface sediments along an eutrophication gradient allowed the following conclusions:

- Overall, 84 infrageneric taxa were reported belonging to 71 species and eight non-typical varieties, besides five identified only to the genus level. From those, $47.6 \%$ were accounted exclusively for the subfossil assemblages indicating a significant biodiversity change over time.

- Our results expanded two new additions for Brazilian diatom flora (Chamaepinnularia submuscicola and Stauroneis acidoclinata), 30 infrageneric taxa for the state of São Paulo and four probable new species.

- Access to past oligotrophic conditions and mesotrophic regions of Guarapiranga Reservoir allowed a significant number of new additions to the Brazilian and the state of São Paulo diatom floras, which accounted for $25 \%$ of the total reservoir flora.

- Human-induced eutrophication led to a sharp decline in the oligotrophic species number, mainly of Eunotia and to a drastic reduction in species richness mainly since the major eutrophication period in ca. 1990.

- Abrupt changes in richness were also caused by human management as the increase in the reservoir's water discharge and the application of algaecide to control cyanobacterial blooms.

- Present findings highlight the need for surveying diatom assemblages in protected environments or in less degraded conditions (considering space and time) for biodiversity assessment, and reinforce the use of paleolimnological approach in many cases as the only tool to access baseline conditions of degraded fresh waters (Smol 2008, GregoryEaves \& Beisner 2011). These issues are crucial given freshwater ecosystems have been experiencing far greater declines in biodiversity than those recorded in terrestrial ecosystems and constitute a valuable natural resource (Dundgeon et al. 2006). Furthermore, cultural eutrophication is considered a common scenario worldwide and one of the most pervasive environmental issues affecting freshwater ecosystems (Smol 2008, Davidson \& Jeppesen 2013, Cumming et al. 2015).

\section{Acknowledgments}

This study was carried out within the framework of the AcquaSed project supported by funds from FAPESP (Fundação de Amparo à Pesquisa do Estado de São Paulo, AcquaSed Project $n^{\circ}$ 2009/53898-9), and was undertaken as part of SBF's M.Sc. dissertation thesis (CAPES fellowship) and LF's Ph.D. thesis (FAPESP doctoral fellowship 08/57139-2). ECRB thanks her doctoral fellowship (FAPESP 2013/14337-7). Funding was also provided by CNPq, Conselho Nacional de Desenvolvimento Científico e Tecnológico (Grant 310940/ 2013-3 to DCB and $309474 / 2010-8$ to CEMB). We thank the valuable assistance of personnel from the agency in charge São Paulo's public water supply - SABESP/RHMS (Companhia de Saneamento do Estado de São Paulo, Divisão de Recursos Hídricos Metropolitanos Sudoeste), who helped with the fieldwork. We gratefully acknowledge Dr. Carlos Wetzel (Luxembourg Institute of Science and Technology - LIST), Dr. Eduardo A. Morales (Universidad Catolica Boliviana San
Pablo, Cochabamba, Bolivia), Livia F. da Costa and Angela Maria S. Lehmkuhl (Instituto de Botânica) and two anonymous reviewers for their valuable constructive comments on the manuscript. We are also grateful to Prof. William de Queiróz (Universidade de Guarulhos, Laboratório de Geoprocessamento) for the illustration of the study area.

\section{References}

ALMEIDA, P.D., WETZEL, C.E., MORALES, E.A., ECTOR, L. \& BICUDO, D.C. 2015. Staurosirella acidophila sp. nov., a new araphid diatom (Bacillariophyta) from southeastern Brazil: ultrastructure, distribution and autecology. Cryptogamie Algol. 36 (3):255-270.

APHA - American Public Health Association. 2005. Standard Methods for the Examination of Water and Wastewater, $21^{\text {st }}$ Edition, American Public Health Association, Washington, DC..

BARTOZEK, E.C.R., BUENO, N.C., LUDWIG, T.A.V., TREMARIN, P.I., NARDELLI, M.S. \& ROCHA, A.C.R. 2013. Diatoms (Bacillariophyceae) of Iguaçu National Park, Foz do Iguaçu, Brazil. Acta Bot. Bras. 27(1):108-123, http://dx.doi.org/10.1590/ S0102-33062013000100012.

BATTARBEE, R.W., JONES, V.J., FLOWER, R.J., CAMERON, N. G., BENNION, H., CARVAlHO, L. \& JUGGinS, S. 2001. Diatoms. In Tracking environmental change using lake sediments. Vol 3: terrestrial, algal, and siliceous indicators (J.P. Smol, H.J.B. Birks \& W.M. Last, eds.). Kluwer, Dordrecht, p.155-202.

BENNION, H. 1995. Surface-sediment diatom assemblages in shallow, artificial, enriched ponds and implications for reconstructing trophic status. Diatom Res. 10(1):1-19, http://dx.doi.org/10.1080/ 0269249X.1995.9705326

BENNION, H. \& SIMPSON, G.L. 2011. The use of diatom records to establish reference conditions for UK lakes subject to eutrophication. J. Paleolimnol. 45(4):469-488, http://dx.doi.org/10.1007/s10933-0109422-8.

BERTHON, V., BOUCHEZ, A. \& RIMET, F. 2011. Using diatom life-forms and ecological guilds to assess organic pollution and trophic level in rivers: a case study of rivers in south-eastern France. Hydrobiol. 673:259-271, http://dx.doi.org/10.1007/s10750011-0786-1.

BERTOLLI, L.M., TREMARIN, P.I. \& LUDWIG, T.A.V. 2010. Diatomáceas perifíticas em Polygonum hydropiperoides Michaux, reservatório do Passaúna, Região Metropolitana de Curitiba, Paraná, Brasil. Acta Bot. Bras. 24(4):1065-1081.

BEYRUTH, Z. 2000. Periodic disturbances, trophic gradient and phytoplankton characteristics related to cyanobacterial growth in Guarapiranga Reservoir, São Paulo State, Brazil. Hydrobiologia 424:51-65, http://dx.doi.org/10.1023/A:1003944726346.

BICCA, A.B., TORGAN, L.C. \& SANTOS, C.B. 2011. Eunotiaceae (Eunotiales, Bacillariophyta) em ambientes lacustres na Planície Costeira do Sul do Brasil. Rev. Bras. Bot. 34(1):1-19.

BICUDO, C.E.M., MORANDI, L.L., ARAÚJO, A., CARNEIRO, L.A. \& BICUDO, D.C. 2009. Algas. In Patrimônio da Reserva Biológica do Alto da Serra de Paranapiacaba: a Antiga Estação Biológica do Alto da Serra (M.I.M.S. Lopes, M. Kirisaura \& M.M.R.F. Melo, eds.). Instituto de Botânica, São Paulo, p.187-212.

BIRKS, H.J.B. 1994. The importance of pollen and diatom taxonomic precision in quantitative palaeoenvironmental reconstructions. Rev. Palaeobot. Palynol. 83:107-117, http://dx.doi.org/10.1016/ 0034-6667(94)90062-0.

BRASSAC, N.M., ATAB, D.R., LANDUCCI, M., VISINONI, N.D. \& LUDWIG, T.V. (1999): Diatomáceas cêntricas de rios da região de abrangência da usina hidrelétrica de Salto Caxias, PR (Bacia do rio Iguaçu). Acta Bot. Bras. 13(3):277-289.

BUCZKÓ, K. \& MAGYARI, E. 2007. The Holocene diatom flora of Lake Saint Anna (Eastern Carapathians, Europe). Alg. Stud. 124:1-28, http://dx.doi.org/10.1127/1864-1318/2007/0124-0001. 
CALIFORNIA ACADEMY OF S.C.I.E.N.C.E.S. 2012. Diatom Collection. California. http://research.calacademy.org/izg/research/ diatom. Accessed 01 February 2014.

CAVALCANTE, K.P., TREMARIN, P.I. \& LUDWIG, T.A.V. 2013. Taxonomic studies of centric diatoms (Diatomeae): unusual nanoplanktonic forms and new records for Brazil. Acta Bot. Bras. 27 (2):237-251, http://dx.doi.org/10.1590/S0102-33062013000200001

COSTA-BÖDDEKER, S., BENNION, H., JESUS, T.A., ALBUQUERQUE, A.L.S., FIGUEIRA, R.C.L. \& BICUDO, D.C. 2012. Paleolimnologically inferred eutrophication of a shallow tropical urban reservoir, Southeast Brazil. J. Paleolimnol. 48(4):751-766, http://dx.doi.org/10.1007/s10933-012-9642-1.

CRAWFORD, R.M., CANTER, H.M. \& JAWORSKI, G.H.M 1985. A Study of Two Morphological Variants of the Diatom Fragilaria crotonensis Kitton using Electron Microscopy. Ann. Bot. 55:473-485.

CROSSETTI, L.O., BICUDO, D.C., BICUDO, C.E.M. \& BINI, L.M. 2008. Phytoplankton biodiversity changes of a shallow tropical reservoir during the hypertrophication process. Braz. J. Biol. 68 (4):631-637, http://dx.doi.org/10.1590/S1519-69842008000500013 .

CUMMING, B.F., LAIRD, K.R., GREGORY-EAVES I., SIMPSON, K.G., SOKAL M.A., NORDIN R.N. \& WALKER I.R. 2015. Tracking past changes in lake-water phosphorus with a 251-lake calibration dataset in British Columbia: tool development and application in a multiproxy assessment of eutrophication and recovery in Osoyoos Lake, a transboundary lake in Western North America. Front. Ecol. Evol. 3:84, http://dx.doi.org/10.3389/fevo.2015. 00084.

CZARNECKI, D.B., KOCIOLEK, J. \& SULLIVAN, M. 1995. Additions and confirmations to the algal flora of Lake Itasca (MN) State Park. III. The intramucilaginous diatom flora of the colonial peritrich ciliate, Ophrydium versatile (Ophrydiidae). In A Century of Diatom Research in North America: A Tribute to the Distinguished Careers of Charles W. Reimer and Ruth Patrick (J.P. Kociolek \& M.J. Sullivan, eds.). Koeltz Scientific Books, p.183194.

DAVIDSON, T.A. \& JEPPESEN, E. 2013. The role of paleolimnology in assessing eutrophication and its impact on lakes. J. Paleolimnol. 49:391-410, http://dx.doi.org/10.1007/s10933-012-9651-0.

DAVIDSON, T.A., REID, M.A., SAYER, C.D. \& CHILCOTT, S. 2013. Palaeolimnological records of shallow lake biodiversity change: exploring the merits of single versus multi-proxy approaches. J. Paleolimnol. 49(3):431-466, http://dx.doi.org/10.1007/s10933013-9696-8.

DELGADO, S.M. \& SOUZA, M.G.M. 2007. Diatomoflórula do rio Descoberto - DF e GO, Brasil, Naviculales (Bacillaruiphyceae) Diploneidineae e Sellaphorineae. Acta Bot. Bras. 21(4):767-776.

DENYS, L. \& STRAATEN, D. 1992. A survey of the acid water diatom assemblages of two heathland relics in the Belgian northern Campine (Groot and Klein Schietveld, Brasschaat) with an assessment of their conservational value. Diatom Res. 7(1):1-13, http://dx.doi.org/10.1080/0269249X.1992.9705193.

DUDGEON, D., ARTHINGTON, A.H., GESSNER, M.O., KAWABATA, Z., KNOWLER, D., LÉVÊQUE, C., NAIMAN, R.J., PRIEUR, R.A.H., SOTO, D. \& STIASSNY, M.L.J. 2006. Freshwater biodiversity: importance, threats, status and conservation challenges. Biol. Rev. 81(2):163-182, http://dx.doi.org/10.1017/S1464793105006950.

EHRENBERG, C.G. 1843.Verbreitung und Einfluss des mikroskopischen Lebens in Süd- und Nord-Amerika. Abh. Königl. Akad. Wiss. Berlin 1841:291-446.

FARIA, D.M., TREMARIN, P.I. \& LUDWIG, T.A.V. 2010. Diatomáceas perifíticas da represa Itaqui, São José dos Pinhais, Paraná: Fragilariales, Eunotiales, Achnanthales e Gomphonema Ehrenberg. Biota Neotropica 10(3): http://www.biotaneotropica.org.br/v10n3/ pt/abstract?article + bn04110032010.

FERRARI，F. \& LUDWIG，T.A.V. 2007. Coscinodiscophyceae, Fragilariophyceae e Bacillariophyceae (Achnanthales) dos rios Ivaí, São João e dos Patos, bacia hidrográfica do rio Ivaí, município de Prudentópolis, PR, Brasil. Acta Bot. Bras. 21(2):421441, http://dx.doi.org/10.1590/S0102-33062007000200016

FONTANA, L. \& BICUDO, D.C. 2009. Diatomáceas (Bacillariophyceae) de sedimentos superficiais dos reservatórios em cascata do Rio Paranapanema (SP/PR, Brasil): Coscinodiscophyceae e Fragilariophyceae. Hoehnea 36(3):375-386.

FONTANA, L. \& BICUDO, D.C. 2012. Biodiversidade e distribuição das diatomáceas (Bacillariophyceae) de sedimentos superficiais nos reservatórios em cascata do Rio Paranapanema (SP/PR, Brasil). Hoehnea 39(4):587-612.

FONTANA, L., ALBUQUERQUE, A.L.S., BRENNER, M., BONOTTO, D.M., SABARIS, T.P.P., PIRES, M.A.F., COTRIM, M.E.B. \& BICUDO, D.C. 2014. The eutrophication history of a tropical water supply reservoir in Brazil. J. Paleolimnol. 51(1):2943, http://dx.doi.org/10.1007/s10933-013-9753-3.

FRENGUELLI, J. 1933. Diatomeas de la region de los esteros del Yberá. An. Mus. Nac. Hist. Nat. 37:365-476.

FROYD, C.A. \& WILLIS, K.J. 2008. Emerging issues in biodiversity \& conservation management: The need for a palaeoecological perspective. Quat. Sci. Revi. 27:1723-1732, http://dx.doi.org/10. 1016/j.quascirev.2008.06.006.

FUREY, P. 2011. Eunotia. Diatoms of the United States. In Diatoms of the United States (S.A. Spaulding, D.J. Lubinski \& M. Potapova, eds.). http://westerndiatoms.colorado.edu/taxa/genus/eunotia. Acessed 23 April 2015.

FUREY, P., LOWE, R.L. \& JOHANSEN, J.R. 2011. Eunotia Ehrenberg (Bacillariophyta) of the Great Smoky Mountais National Park, USA. Bibliotheca Diatomologica 56, p.1-133.

GAISER, E.E. \& JOHANSEN, J. 2000. Freshwater diatoms from Carolina Bays and other isolatedt Wetlands on the Atlantic Coastal Plain of South Carolina, USA, with descriptions of seven taxa new to science. Diatom Res. 15(1):75-130, http://dx.doi.org/ 10.1080/0269249X.2000.9705487.

GENKAL, S.I. \& KISS, K.T. 1993. Morphological variability of the diatom Cyclotella atomus Hustedt var.atomus and C. atomus var. gracilis var. nov. Hydrobiol. 269/270: 39-47, http://dx.doi.org/ 10.1007/BF00028002.

GREGORY-EAVES, I. \& BEISNER, B.E. 2011. Palaeolimnological insights for biodiversity science: an emerging field. Freshwater Biol. 56:2653-2661, http://dx.doi.org/10.1111/j.1365-2427.2011.02677.x.

GRENIER, M., CAMPEAU, S., LAVOIE, I., PARK, Y.S. \& LEK, S. 2006. Diatom reference communities in Quebec (Canada) streams based on Kohonen self-organizing maps and multivariate analyses. Can. J. Fish. Aquat. Sci. 63(9):2087-2106, http://dx.doi.org/10.1139/ f06-101.

GUIRY, M..D. In GUIRY, M..D. \& GUIRY, G.M. 2016. AlgaeBase. World-wide electronic publication, National University of Ireland, Galway. http://www.algaebase.org; searched on 06 January 2016.

HéKANSSON, H. \& CLARKE, K.B. 1997. Morphology and taxonomy of the centric diatom Cyclotella atomus. Nova Hedwigia 65:207-219.

HLUBIKOVA, D., ECTOR, L. \& HOFFMANN, L. 2011. Examination of the type material of some diatom species related to Achnanthidium minutissimum (Kutz.) Czarn. (Bacillariophyceae). Algol. Stud. 136/ 137:19-43, http://dx.doi.org/10.1127/1864-1318/2011/0136-0019.

HOFMANN, G. 1994. Aufwuchs diatoms in Seen und ihre Eignung als Indikatoren der Trophie. Cramer, Berlin-Stuttgart. Biblioteca Diatomologica 30, p.1-241.

HOUK, V. \& KLEE, R. 2007. Atlas of freshwater centric diatoms with a brief key and descriptions Part II. Melosiraceae and Aulacoseiraceae (Supplement to Part I). Fottea 7(2):85-255.

HUSTEDT, F. 1950. Die Diatomeenflora nordddeutscher Seen mit besonderer Berücksitgung des holsteinischen Seengebies V-VII. Seen in Mecklenburg, Lauenburg und Nordostdeutschland. Arch. Hydrobiol. 43:329-458.

IBARRA, C., TAVERA, R. \& NOVELO, E. 2009. Diversidad y estructura de las comunidades de diatomeas del perifiton y el 
metafiton en un humedal tropical en México. Rev. Mex. Biodiversid. 80(3):763-769.

IBGE -Instituto Brasileiro de Geografia e Estatística. 2014. São Paulo. http://www.cidades.ibge.gov.br/xtras/uf.php?lang $=\&$ coduf $=35$ $\&$ search $=$ sao-paulo (accessed 19 September 2015).

KISS, K.T., KLEE, R., ECTOR, L. \& ÁCS, É. 2012. Centric diatoms of large rivers and tributaries in Hungary: morphology and biogeographic distribution. Acta Bot. Croat. 71(2):311-362.

KOBAYASI, H., IDEI, M., MAYAMA, S., NAGUMO, T. \& OSADA, K. 2006. Atlas of Japanese Diatoms based on electron microscopy. Tokyo: Uchida Rokakuho Publishing Co. Ltd..

KRAMMER, K. 2000. The genus Pinnularia. Diatoms of Europe vol. 1, p.1-703.

KRAMMER, K. \& LANGE-BERTALOT, H. 1991. Bacillariophyceae, part 3: Centrales, Fragilariaceae, Eunotiaceae. In Süßwasserflora von Mitteleuropa 2/3 (H. Ettl, J. Gerloff, H. Heynig \& D. Mollenhauer, eds.). Gustav Fischer Verlag, Stuttgart, p.1-576.

LAMPARELLI, M.C. 2004. Graus de trofia em corpos d'água do Estado de São Paulo: Avaliação dos métodos de monitoramento. São Paulo: Universidade de São Paulo. Tese de Doutorado, Universidade de São Paulo, São Paulo.

LANGE-BERTALOT, H. 1993. 85 Neue Taxa und über 100 weitere neu definierte Taxa ergänzend zur Süßwasserflora von Mitteleuropa. Bibliotheca Diatomologica 27, p.1-454.

LANGE-BERTALOT, H. \& MOSER, G. 1994. Brachysira Monographie der Gattung. Wichtige Indikator Species für das Gewässermonitoring und Naviculadicta nov. gen. Bibliotheca Diatomologica 29, p.1-212.

LANGE-BERTALOT, H. \& ULRICH, S. 2014. Contributions to the taxonomy of needle-shaped Fragilaria and Ulnaria species. Lauterbornia 78:1-73.

LANGE-BERTALOT, H., BAK, M. \& WITKOWSKI, A. 2011. Diatoms of the European Inland Water and Comparable Habitats. Eunotia and some related genera. In Diatoms of Europe $6(\mathrm{H}$. Lange-Bertalot, ed.), p.1-747.

LAUX, M. \& TORGAN, L.C. 2011. Diatomáceas com plastídeos no plâncton da foz dos rios do Delta do Jacuí, Sul do Brasil: um complemento à taxonomia tradicional. Iheringia 66(1):109-132.

LEVKOV, Z., METZELTIN, D. \& PAVLOV, A. 2013. Luticola and Luticolopsis. In Diatoms of Europe vol 7 (H. Lange-Bertalot, ed.), p.1-698.

LIU, J., LIN, Z., ZHANG, H. \& HAN, B.P. 2012. Hydrodynamic change recorded by diatoms in sediments of Liuxihe Reservoir, Southern China. J. Paleolimnol. 47(1):17-27, http://dx.doi.org/ 10.1007/s10933-011-9543-8.

LOWE, R.L. 1975. Comparative ultrastructure of the valves of some Cyclotella species (Bacillariophyceae). J. Phycol. 11(4):415-424, http://dx.doi.org/10.1111/j.1529-8817.1975.tb02805.x.

LUCHINI, L. \& VERONA, C.A. 1972. Catálogo de las diatomeas Argentinas. Comision de Investigaciones Cientfficas de la Provincia de Buenos Aires.

LUDWIG, T.A.V., FLÔRES, T.L., MOREIRA-FILHO, H. \& VEIGA, L.A.S. 2004. Inventário florístico das diatomáceas (Ochrophyta) de lagoas do Sistema Hidrológico do Taim, Rio Grande do Sul, Brasil. Iheringia 59(1):97-106.

LUDWIG, T.A.V., BIGUNAS, P.I.T., NEIVA, T.F., COQUEMALA, V. \& PICCININI, C. 2005. Diatomáceas (Ochrophyta) dos lagos do Jardim Botânico. Pp. 301-323. In Reunião Brasileira de Ficologia, 2004, Salvador. Formação de Ficólogos: um compromisso com a sustentabilidade dos recursos aquáticos. Rev. Mus. Nac. Rio de Janeiro (Série Livros 10).

MAGURRAN, A.E. 2004. Measuring Biological Diversity. United Kingdom: Blackwell Publishing, p. 1-256, http://dx.doi.org/10.1186/ 1471-2180-12-121.

MANN, D.G., McDONALD, S.M., BAYERI, M.M., DROOP, S.M., CHEPURNOVI, V.A., LOKE, R.E., CIOBANU, A. \& DU BUF, J.M.H. 2004. The Sellaphora pupula species complex (Bacillariophyceae): morphometric analysis, ultrastructure and mating data provide evidence for five new species. Phycologia 43(4):459-482, http://dx.doi.org/10.2216/i0031-8884-43-4-459.1.

MANN, D., THOMAS, S.J. \& EVANS, K.M. 2008. Revision of the diatom genus Sellaphora: a first account of the larger species in the British Isles. Fottea 8(1):15-78.

MEDLIN, L.K. \& KACZAMARSKA, I. 2004. Evolution of the diatoms V. Morphological and cytological support for the major clades and taxonomic revision. Phycologia 43:245-270, http://dx. doi.org/10.2216/i0031-8884-43-3-245.1.

MELLO, S., TORGAN, L.C. \& RAUPP, S.V. 2010. Actinella species (Bacillariophyta) from an Amazon black water floodplain lake (Amazonas - Brazil). Acta Amaz. 40(2):269-274, http://dx.doi.org/ 10.1590/S0044-59672010000200004 .

METZELTIN, D. \& LANGE-BERTALOT, H. 1998. Tropical Diatoms of South America I. About 700 predominantlye rarely know or new taxa representative of the neotropical flora. In Iconographia Diatomologica 5 (H. Lange-Bertalot, ed.), p.1-695.

METZELTIN, D. \& LANGE-BERTALOT, H. 2007. Tropical Diatoms of the South America II. Special remarks on biogeographic disjunction. In Iconografia Diatomologica 18 (H. Lange-Bertalot, ed.), p.1-877.

METZELTIN, D. \& WITKOWSKI, A. 1996. Diatomeen der BärenInsel. Süsbwasser- und marine Arten. In Iconographia Diatomologica 4 (H. Lange-Bertalot, ed.), p.1-287.

METZELTIN, D., LANGE-BERTALOT, H. \& RODRÍGUEZGARCÍA, F. 2005. Diatoms of Uruguay compared with other taxa from South America and elsewhere. In Iconographia Diatomologica 15 (H. Lange-Bertalot, ed.), p.1-736.

MORANDI, L.L., RITTER, L.M.O., MORO, R.S. \& BICUDO, C.E.M. 2006. Criptógamos do Parque Estadual das Fontes do Ipiranga, São Paulo, SP. Algas, 20: Coscinodiscophyceae. Hoehnea 33(1):115-122.

MORO, R.S. 1991. Morphology of Aulacoseira granulata (Ehrenberg) Simonsen var. australiensis (Grunow) nov. com. under light microscophy. Arq. Biol. Tec. 34(2):353-359.

MORO, R.S. \& FÜRSTENBERGER, C.B. 1993. Diatomáceas (Bacillariophyceae) da Lagoa Dourada (Parque Estadual de Vila Velha), Paraná, Brasil. Acta Biol. Paran. 22:15-30, http://dx.doi. org/10.5380/abpr.v22i0.718

MORO, R.S. \& FÜRSTENBERGER, C.B. 1997. Catálogo dos principais parâmetros ecológicos de diatomáceas não-marinhas. Editora da Universidade Estadual de Ponta Grossa, Ponta Grossa, p. 1-282.

MOZETO, A.A., SILVÉRIO, P.F. \& SOARES, A. 2001. Estimates of benthic fluxes of nutrients across the sediment-water interface (Guarapiranga reservoir, São Paulo, Brazil). Sci. Total Envir. 266:135-142, http://dx.doi.org/10.1016/S0048-9697(00)00726-9.

PATRICK, R. \& REIMER, C.W. 1966. The Diatoms of United States. Vol I. The Academy of Natural Sciences of Philadelphia, p. 1-688.

POTAPOVA, M. \& CHARLES, D.F. 2003. Distribution of benthic diatoms in US rivers in relation to conductivity and ionic composition. Fresh. Biol. 48(8):1311-1328, http://dx.doi.org/10.1046/ j.1365-2427.2003.01080.x.

POTAPOVA, M. \& CHARLES, D.F. 2007. Diatom metrics for monitoring eutrophication in Rivers of the United States. Ecolog. Indic. 7:48-70, http://dx.doi.org/10.1016/j.ecolind.2005.10.001.

POTAPOVA, M. \& SPAULDING, S. 2013. Cocconeis placentula. In Diatoms of the United States. http://westerndiatoms.colorado.edu/ taxa/species/cocconeis_placentula. Acessed 06 January 2016.

RAUPP, S.V., TORGAN, L.C. \& BAPTISTA, L.R.M. 2006. Composição e variação temporal de diatomáceas (Bacillariophyta) no plâncton da represa de Canastra, sul do Brasil. Iheringia, Sér. Bot., 61(1-2):105-134.

REID, M. 2005. Diatom based models for reconstructing past water quality and productivity in New Zealand Lakes. J. Paleolimnol. 33 (1):13-38, http://dx.doi.org/10.1007/s10933-004-0424-2.

ROCHA, A.C.R. \& BICUDO, C.E.M. 2008. Criptógamos do Parque Estadual das Fontes do Ipiranga, São Paulo, SP. Algas, 25: Bacillariophyceae (Naviculales: Pinnulariaceae). Hoehnea 35 (4):597-618, http://dx.doi.org/10.1590/S2236-89062008000400011 
RODRIGUES, L. 1984. Contribuição ao conhecimento das diatomáceas do rio Tubarão, Santa Catarina, Brasil. Ínsula 14:47-120.

ROMERO, O.E. \& JAHN, R. 2013. Typification of Cocconeis lineata and Cocconeis euglypta (Bacillariophyta). Diatom Res. 28(2): 175-184, http://dx.doi.org/10.1080/0269249X.2013.770801.

ROUND, F.E., CRAWFORD, R.M. \& MANN, D.G. 1990. The diatoms. Biology and morphology of the genera. New York, Cambridge University Press, p.129.

SANTOS, E.M., TRENARIN, P.I. \& LUDWIG, T.A.V. 2011. Diatomáceas perifíticas em Potamogeton polygonus Cham. \& Schltdl.: citações pioneiras para o estado do Paraná. Biota Neotropica 11 (3): http://www.biotaneotropica.org.br/v11n3/ en/abstract?inventory + bn01611032011.

SARTORY, D.P. \& GROBBELAAR, J.U. 1984. Extraction of chlorophyll a from freshwater phytoplankton for spectrophotometric analysis. Hydrobiologia 114:177-187, http://dx.doi. org/10.1007/BF00031869.

SCHMIDT, R., MÄUSBACHER, R. \& MÜLLER, J. 1990. Holocene diatom flora and stratigraphy from sediment cores of two Antartic lakes (King George Island). J Paleolimnol 3(1): 55-74, http://dx. doi.org/10.1007/BF00209300.

SILVA, P.D.A. \& BICUDO, D.C. 2014. Diatomáceas planctônicas e de sedimentos superficiais em represas de abastecimento da Região Metropolitana de São Paulo, Sudeste do Brasil. Hoehnea 41(2):187-207.

SILVA, A.M., LUDWIG, T.A.V., TREMARIN, P.I. \& VERCELLINO, I. S. 2010. Diatomáceas perifiticas em um sistema eutrófico brasileiro (Reservatório do Iraí, estado do Paraná). Acta Bot. Bras. 24(4):997-1016.

SILVA, W..J. JAHN, R. \& MENEZES, M. 2012. Diatoms from Brazil: the taxa recorded by Christian Gottfried Ehrenberg. PhytoKeys 18: 19-37, http://dx.doi.org/10.3897/phytokeys.18.3653.

SIVER, P.A. \& KLING, H. 1997. Morphological observations of Aulacoseira using scanning electron microscopy. Can. J. Bot. 75:1807-1835, http://dx.doi.org/10.1139/b97-894.

SMOL, J.P. 2008. Pollution of lakes and rivers: a paleoenvironmental perspective. 2 ed. 383 p.

STENGER-KOVÁCS, C., BUCZKÓ, K., HAJNAL, E. \& PADISÁK, J. 2007. Epiphytic, littoral diatoms as bioindicators of shallow lake trophic status: Trophic diatom index for lakes (TDIL) developed in Hungary. Hydrobiologia 589:141-154, http://dx.doi.org/10.1007/s10661-011-2295-0.

STRAYER, D. \& DUDGEON, D. 2010. Freshwater biodiversity conservation: recent progress and future challenges. J. North Am. Benthol. Soc. 29:344-358, http://dx.doi.org/10.1899/08-171.1.

TAVARES, B. \& VALENTE-MOREIRA, I.M. 2000. Diatomoflórula do lago de Cascavel, município de Cascavel, estado do Paraná, Brasil. Hoehnea 27(1):1-24.

TAYLOR, J.C., HARDING, W.R. \& ARCHIBALD, G.M. 2007. An Illustrated Guide to Some Common Diatom Species from South Africa. WRC Report TT 282(7), p.224.
TUJI, J. \& WILLIAMS, D.M. 2007. Type examination of Japanese diatoms described by Friedrich Meister (1913) from Lake Suwa. Bull. Natl. Sci. Mus., Ser. B 33(2):69-79.

VAN DAM, H., MERTENS, A. \& SINKELDAM, J. 1994. A coded checklist and ecological indicator values of freshwater diatoms from the Netherlands. Net. J. Aquat. Ecol. 28:117-133, http://dx. doi.org/10.1007/BF02334251.

VAN HEURCK, H. 1885. Synopsis des diatomées de Belgique. Martin Brouwers \& Co., Anvers, p. 235.

YANG, J.R. \& DICKMAN, M. 1993. Diatoms as indicators of lake trophic status in central Ontario, Canada. Diatom Res. 8(1): 179-193, http://dx.doi.org/10.1080/0269249X.1993.9705249.

WENGRAT, S. \& BICUDO, D.C. 2011. Spatial evaluation of water quality in an urban reservoir (Billings Complex, southeastern Brazil). Acta Limnol. Bras. 23(2):200-216, http://dx.doi.org/10.1590/S2179975X2011000200010.

WENGRAT, S., MARQUARDT, G.C., BICUDO, D.C., BICUDO, C.E.M., WETZEL, C.E. \& ECTOR, L. 2015. Type analysis of Cymbella schubartii and two new Encyonopsis species (Bacillariophyceae) from southeastern Brazil. Phytotaxa 221(3):247-264, http://dx.doi.org/ 10.11646/phytotaxa.221.3.3.

WERUM, M. \& LANGE-BERTALOT, H. 2004. Diatoms in springs from Central Europe and elsewhere under the influence of hydrogeology and anthropogenic impacts. In Iconographia Diatomologica 13 (H. Lange-Bertalot, ed.), p.1-480.

WETZEL, C.E. 2011. Biodiversidade e distribuição espacial de diatomáceas (Bacillariohyceae) na bacia hidrográfica do rio Negro, Amazonas, Brasil. Tese de doutorado, Instituto de Botânica, São Paulo, p. 1-1876.

WETZEL, C.E. \& ECTOR, L. 2014. Taxonomy, distribution and autecology of Planothidium bagualensis sp. nov. (Bacillariophyta) a common monoraphid species from southern Brazilian rivers. Phytotaxa 156 (4):201-210.

WETZEL, C.E., ECTOR, L., HOFFMANN, L. \& BICUDO, D.C. 2010. Colonial planktonic Eunotia (Bacillariophyceae) from Brazilian Amazon: Taxonomy and biogeographical considerations on the E. asterionelloides species complex. Nova Hedwigia 91(12):49-86, http://dx.doi.org/10.1127/0029-5035/2010/0091-0049.

WHATELY, M. \& CUNHA, P.M. 2006. Guarapiranga 2005: como e por que São Paulo está perdendo este manancial. Resultados do diagnóstico socioambiental participativo da Bacia Hidrográfica do Guarapiranga. ISA - Instituto Socioambiental, p. $1-51$.

WOLFE, A.P. \& KLING, H.J. 2001. A consideration of some North American soft-water Brachysira taxa and description of B. arctoborealis sp. nov. In Studies on Diatoms (R. Jahn, J.P. Kociolek, A. Witkowski, P. Compère \& H. Lange-Bertalot). Koeltz, Koenigstein, p. $243-264$ 